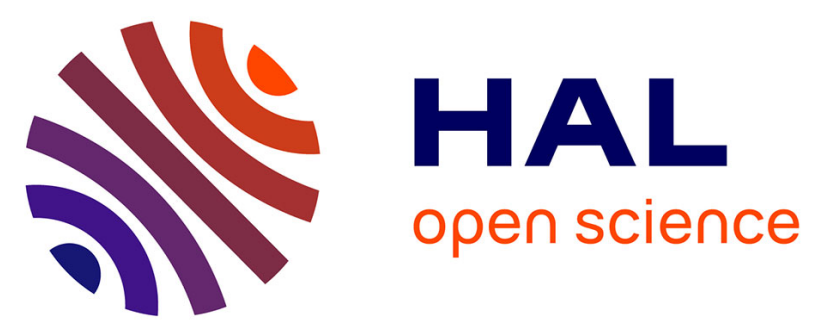

\title{
Kinematic and moisture characteristics of a nonprecipitating cold front observed during IHOP. Part I: Across-front structures
}

\author{
Katja Friedrich, David E. Kingsmill, Cyrille Flamant, Hanne V. Murphey, \\ Roger M. Wakimoto
}

\section{To cite this version:}

Katja Friedrich, David E. Kingsmill, Cyrille Flamant, Hanne V. Murphey, Roger M. Wakimoto. Kinematic and moisture characteristics of a nonprecipitating cold front observed during IHOP. Part I: Across-front structures. Monthly Weather Review, 2008, 136 (1), pp.147-172. 10.1175/2007MWR1908.1. hal-00261441

\section{HAL Id: hal-00261441 \\ https://hal.science/hal-00261441}

Submitted on 22 Dec 2020

HAL is a multi-disciplinary open access archive for the deposit and dissemination of scientific research documents, whether they are published or not. The documents may come from teaching and research institutions in France or abroad, or from public or private research centers.
L'archive ouverte pluridisciplinaire HAL, est destinée au dépôt et à la diffusion de documents scientifiques de niveau recherche, publiés ou non, émanant des établissements d'enseignement et de recherche français ou étrangers, des laboratoires publics ou privés. 


\title{
Kinematic and Moisture Characteristics of a Nonprecipitating Cold Front Observed during IHOP. Part I: Across-Front Structures
}

\author{
KATJA FRIEDRICH* AND DAVID E. KingSMILL \\ CIRES, University of Colorado, and NOAA/Earth System Research Laboratory, Boulder, Colorado \\ Cyrille Flamant \\ Institut Pierre-Simon Laplace/Service d'Aeronomie, Paris, France \\ Hanne V. Murphey And Roger M. Wakimoto ${ }^{+}$ \\ Department of Atmospheric Sciences, University of California, Los Angeles, Los Angeles, California
}

(Manuscript received 9 June 2006, in final form 19 April 2007)

\begin{abstract}
A wide array of ground-based and airborne instrumentation is used to examine the kinematic and moisture characteristics of a nonprecipitating cold front observed in west-central Kansas on 10 June 2002 during the International $\mathrm{H}_{2} \mathrm{O}$ Project (IHOP). This study, the first of two parts, is focused on describing structures in the across-front dimension. Coarsely resolved observations from the operational network and dropsondes deployed over a 200-km distance centered on the front are combined with higher-resolution observations from in situ sensors, Doppler radars, a microwave radiometer, and a differential absorption lidar that were collected across a $\sim 40-\mathrm{km}$ swath that straddled a $\sim 100-\mathrm{km}$ segment of the front.

The northeast-southwest-oriented cold front moved toward the southeast at $\sim 8-10 \mathrm{~m} \mathrm{~s}^{-1}$ during the morning hours, but its motion slowed to less than $1 \mathrm{~m} \mathrm{~s}^{-1}$ in the afternoon. In the early afternoon, the cold front separated cool air with a northerly component flow of $2-4 \mathrm{~m} \mathrm{~s}^{-1}$ from a $10-\mathrm{km}$-wide band of hot, dry air with $5 \mathrm{~m} \mathrm{~s}^{-1}$ winds out of the south-southwest. The average updraft at the frontal interface was $\sim 0.5$ $\mathrm{m} \mathrm{s}^{-1}$ and slightly tilted back toward the cool air. A dryline was located to the southeast of the front, separating the hot, dry air mass from a warm, moist air mass composed of $10 \mathrm{~m} \mathrm{~s}^{-1}$ southerly winds. Later in the afternoon, the warm, moister air moved farther to the northwest, approaching the cold front. The dryline was still well observed in the southwestern part of the observational domain while it vanished almost completely in the northeastern part. Low-level convergence $\left(\sim 1 \times 10^{-3} \mathrm{~s}^{-1}\right)$, vertical vorticity $\left(\sim 0.5 \times 10^{-3}\right.$ $\left.\mathrm{s}^{-1}\right)$, and vertical velocity $\left(\sim 1 \mathrm{~m} \mathrm{~s}^{-1}\right)$ increased. The strong stable layer located at $\sim 2.0-2.5 \mathrm{~km}$ MSL weakened in the course of the afternoon, providing a basis for the development of isolated thunderstorms. The applicability of gravity current theory to the cold front was studied. There was evidence of certain gravity current characteristics, such as Froude numbers between 0.7 and 1.4, a pronounced feeder flow toward the leading edge, and a rotor circulation. Other characteristics, such as a sharp change in pressure and lobe and cleft structures, remain uncertain due to the temporally and spatially variable nature of the phenomenon and the coarse resolution of the measurements.
\end{abstract}

\section{Introduction}

Boundary layer convergence zones (or boundaries) have long been known to be key factors in convection

\footnotetext{
* Current affiliation: University of Colorado, Boulder, Colorado.

+ Current affiliation: National Center for Atmospheric Research, Boulder, Colorado.
}

Corresponding author address: Katja Friedrich, ATOC, University of Colorado, UCB 311, Boulder, CO 80309-0311.

E-mail: katja.friedrich@colorado.edu initiation and evolution (e.g., Byers and Braham 1949; Wilson and Schreiber 1986; Cohen and Kreitzberg 1997; Cohen and Schultz 2005). An examination of the literature suggests that boundaries such as gust fronts (e.g., Charba 1974; Wakimoto 1982; Weckwerth and Wakimoto 1992; Friedrich et al. 2005), sea-breeze fronts (e.g., Blanchard and Lopez 1985; Atkins et al. 1995; Fovell 2005), and drylines (e.g., Fujita 1970; Koch and McCarthy 1982; Schaefer 1986; Hane et al. 1997; Murphey et al. 2006) have received the largest amount of attention in terms of documenting their kinematic and moisture characteristics for convective weather 
forecasting applications. Precipitating cold fronts, particularly those associated with narrow cold frontal rainbands, have been examined in this context as well (e.g., James and Browning 1979; Hobbs and Persson 1982; Carbone 1982; Roux et al. 1993; Braun et al. 1997; Koch et al. 1997; Wakimoto and Bosart 2000; Jorgensen et al. 2003; Schultz and Trapp 2003).

There is far less detailed observational documentation of nonprecipitating cold fronts. Shapiro (1984), Young and Johnson (1984), and Shapiro et al. (1985) used instrumented tower data to reveal the detailed vertical structure of a cloud-free cold front propagating through northeast Colorado. Similar approaches were employed by Garratt (1988) and Smith et al. (1995) for studies of nonprecipitating cold fronts in Australia, except they relied on sounding and profiler data for their observed inferences. A more detailed case study analysis of this type of interaction was performed by Koch and Clark (1999) for a nonprecipitating cold front observed in Oklahoma. Single-Doppler radar observations were accompanied by surface, sounding, satellite, and profiler data to explore the interaction of a nonprecipitating cold front propagating into a shallow stable layer and then merging with a quasi-stationary dryline. The single-Doppler radar observation available in their study provided an illuminating horizontal context for the structure of the interaction, but threedimensional wind fields could not be derived. Brandes and Rabin (1991) also examined a nonprecipitating cold front in Oklahoma, but had the benefit of dualDoppler-derived wind fields. Their analyses depict a gradual turning of the horizontal winds at the frontal interface, but the grid spacing $(1 \mathrm{~km})$ was too coarse to resolve finescale details such as the presence or absence of misocyclones. Some of these shortcomings were addressed by Neiman and Wakimoto (1999), who analyzed a nonprecipitating cold front observed in north Texas and southwestern Oklahoma. Higher-resolution $(0.6 \mathrm{~km})$ dual-Doppler winds were derived and vertical structure was explored, allowing a detailed spatial examination of the front as it moved over a shallow arctic air mass. A limiting factor in their study is that only one analysis time was available for investigation of the cold front prior to its merger with a dryline, a fact that did not permit discussion of cold frontal evolutionary character.

Datasets from the 13 May to 25 June 2002 International $\mathrm{H}_{2} \mathrm{O}$ Project (IHOP; Weckwerth et al. 2004) provide an opportunity to examine the kinematic and moisture structures of boundaries such as nonprecipitating cold fronts with unprecedented detail. Arnott et al. (2006) examined the finescale ( $100 \mathrm{~m}$ and $90 \mathrm{~s})$ structure of the nonprecipitating cold front on 10 June 2002, with an emphasis on misocyclones observed along and adjacent to the front and the associated cloud development and decay. However, their analysis was confined to a $20 \mathrm{~km} \times 20 \mathrm{~km}$ domain that straddled the front. Our two-part study extends the Arnott et al. (2006) analysis by investigating a much larger spatial domain, up to $200 \mathrm{~km}$ across the front and up to $100 \mathrm{~km}$ along the front. Friedrich et al. (2007, manuscript submitted to Mon. Wea. Rev., hereafter Part II) will focus on kinematic and moisture variability observed along the front while in this paper the emphasis will be on the across-front, kinematic, and moisture structures.

\section{Case overview}

The surface analysis on 10 June 2002 shown in Fig. 1 indicates a surface cold front that extended from central Nebraska, through western Kansas and into eastern Colorado. During the morning to early afternoon hours, ${ }^{1}$ the cold front moved toward the southeast at $\sim 8-10 \mathrm{~m} \mathrm{~s}^{-1}$. A dryline evident in eastern New Mexico and southeastern Colorado at 1200 UTC extended northward along a lee trough (Martin et al. 1995; Hobbs et al. 1996) toward a low pressure center positioned in close proximity to the front (Fig. 1a). As the cold front moved southeastward, the north end of the dryline moved to the east (Figs. 1b,c) in a manner similar to that described by Hutchinson and Bluestein (1998) and Schultz (2004) for prefrontal wind shift lines.

By 1900 UTC, the portion of the cold front in west Kansas slowed its southeastward movement to less than $1 \mathrm{~m} \mathrm{~s}^{-1}$ (Fig. 2a). Surface observations indicate a confluence zone (deformation and horizontal convergence) and a temperature gradient from the southeast to northwest associated with the cold front, conditions conducive to frontogenesis (Keyser et al. 1988). While the deformation zone and horizontal convergence, both frontogenetical processes, were still observed later in the afternoon (Fig. 2b), the temperature gradient was weaker, an indication that frontolysis has occurred. Arnott et al. (2006) discuss in more detail the thermodynamic structure and evolution of the front. They concluded that the increase in temperature within the cool air was due to diabatic heating, which in turn caused a weakening of the frontal circulation.

The location of the cold front leading edge within the outer IHOP observational domain (Box A in Fig. 2a) appears as a thin line of enhanced reflectivity (4-10 $\mathrm{dBZ}$ ) oriented in a northeast-southwest direction (Figs. 3a,c). Surface observations within this domain

\footnotetext{
${ }^{1}$ Local time is UTC $-5 \mathrm{~h}$.
} 


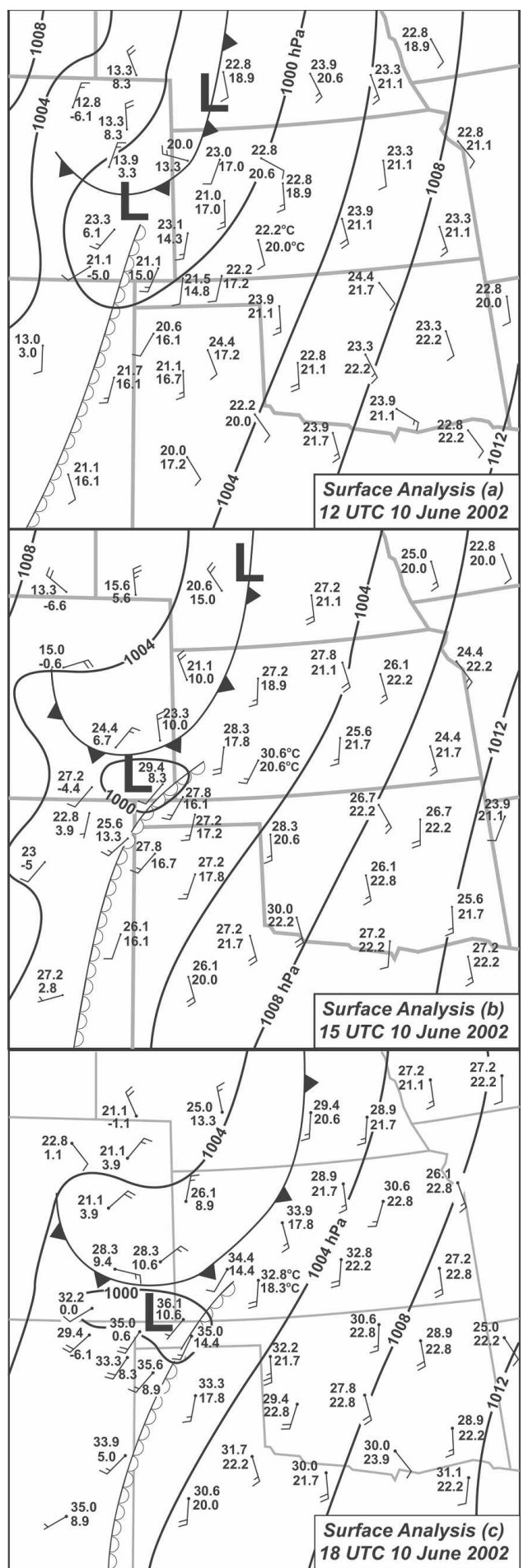

FIG. 1. Surface wind (half barb is $2.5 \mathrm{~m} \mathrm{~s}^{-1}$ and full barb is 5 $\mathrm{m} \mathrm{s}^{-1}$ ), temperature (top number, ${ }^{\circ} \mathrm{C}$ ), dewpoint temperature (bottom number, ${ }^{\circ} \mathrm{C}$ ), and isobars (hPa) at (a) 1200, (b) 1500, and (c) 1800 UTC 10 Jun 2002 overlaid on a map showing the state borders as gray lines. The location of the surface cold front is shown as a black line with alternating filled triangle symbols. The dryline is indicated as a black line with unfilled semicircles attached. indicate a second, more diffuse boundary ahead of (i.e., to the southeast of) the cold front with horizontal gradients of moisture and wind. This secondary boundary was clearly evident in the western half of the IHOP observational domain (i.e., $>100^{\circ} \mathrm{W}$ ) through examination of surface meteorology observations and radar reflectivity (Figs. 3 and 4). The region between the front and secondary boundary is characterized by a hot, dry air mass with southwesterly winds (see surface observations at Garden City, Ness City, and Hays, Kansas; Fig. 3), while southeast of the secondary boundary, winds are southerly and the air mass is moister and warm. Another signature of the secondary boundary is a distinct gradient in radar reflectivity, with values mainly below $0 \mathrm{dBZ}$ in the hot, dry air mass and above $0 \mathrm{~dB} Z$ in the warm, moister air mass. An exception to this pattern is found in the hot, dry air mass, where a line of enhanced reflectivity $(5-10 \mathrm{~dB} Z)$ paralleling the secondary boundary is evident (Figs. 3 and 4). This line of reflectivity and its relationship to the secondary boundary will be discussed in more detail in Part II. In the eastern part of the observational domain (i.e., $<100^{\circ} \mathrm{W}$ ), the location of the secondary boundary is less evident with these data, but is drawn based on dropsonde and aircraft data that will be shown later. Overall, the observational evidence suggests that the secondary boundary has characteristics similar to a dryline. Since the western extent of the secondary boundary is in close proximity to the eastern extent of the large-scale dryline shown in Fig. 1, we hypothesize that the secondary boundary is an extension of the large-scale dryline. The evolution of this dryline within the IHOP observational domain will be discussed in more detail in section 4 based on higher-resolution measurements.

Thermodynamic conditions in the warm, moister air mass became more favorable for convection initiation as the afternoon advanced. Table 1 lists thermodynamic parameters for the warm, moister air measured by the Dodge City (DDC) sounding located in the outer observational domain (DDC location shown in Figs. $3 \mathrm{~b}, \mathrm{~d})$. Convective available potential energy (CAPE) increased, convective inhibition (CIN) decreased, and the level of free convection (LFC) lowered with time. Cumulonimbus clouds first developed along the cold front at about 1930 UTC and several convective cells were observed after 2030 UTC (Figs. 2b and 3c). Cloud development along the cold front on 10 June 2002 was investigated in more detail by Arnott et al. (2006).

\section{IHOP observing systems and data processing}

The analysis of thermodynamic and kinematic structures associated with the cold front is focused on ob- 


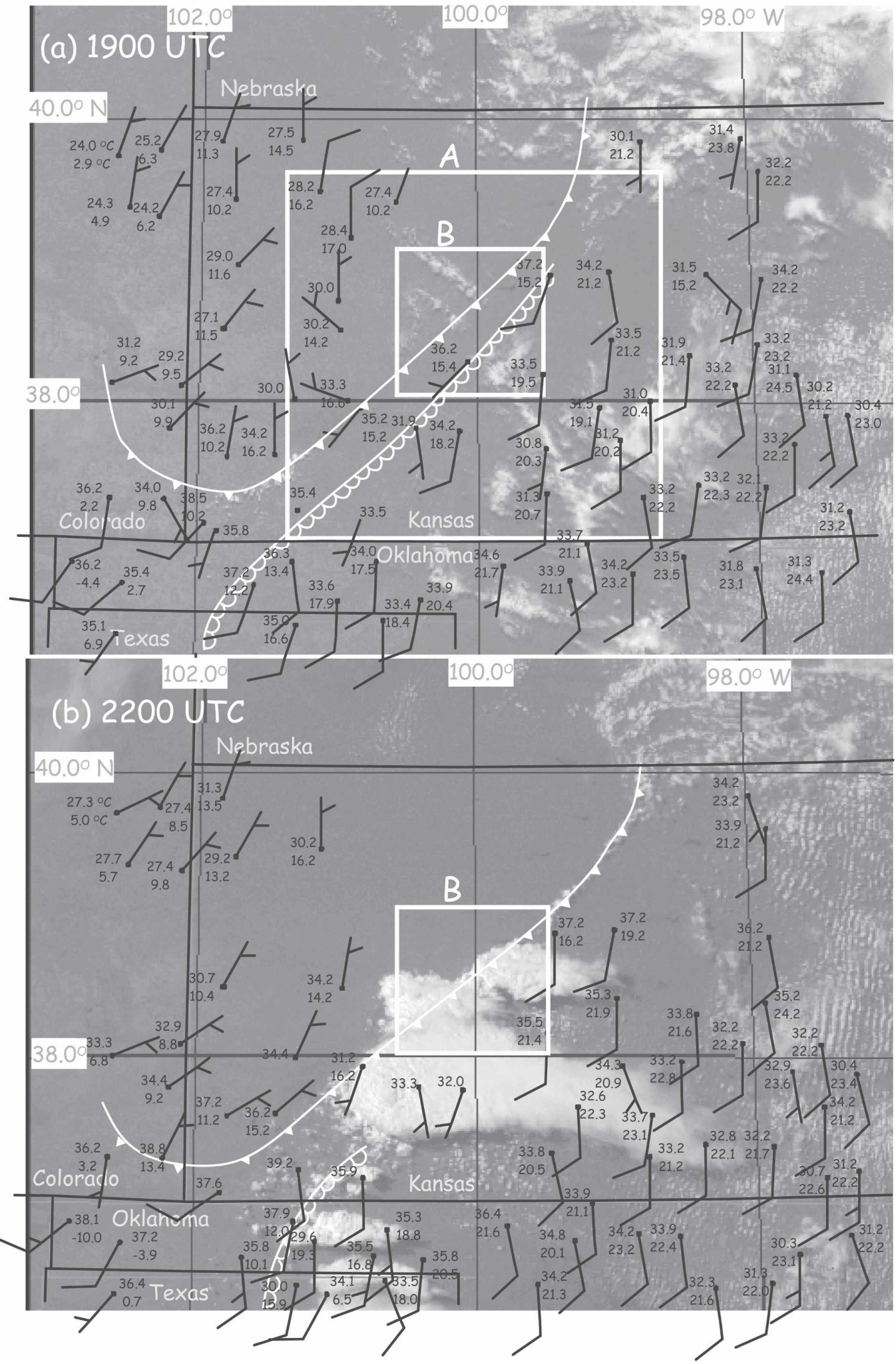

FIG. 2. Surface observations overlaid on GOES-11 visible satellite image (1-km resolution) at (a) 1900 and (b) 2200 UTC. Plotting convections for wind, temperature, dewpoint temperature, the cold front, and the dryline are the same as in Fig. 1. The outer observational domain is located in the white box labeled A, while the inner observational domain is located within the white box labeled $\mathrm{B}$. 


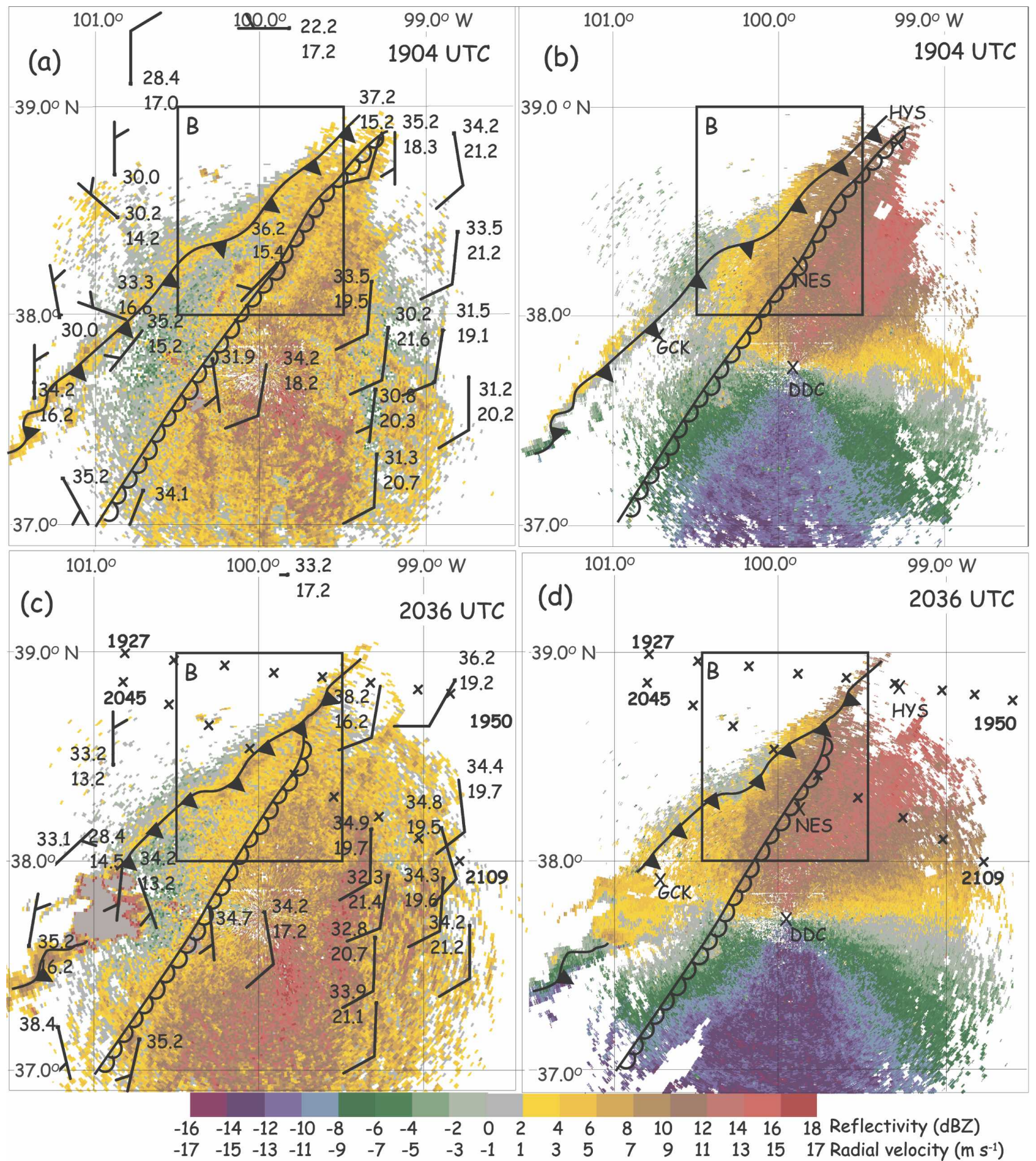

FIG. 3. Color-coded (a), (c) radar reflectivity and (b), (d) Doppler velocity (scales at the bottom) measured by the Dodge City WSR-88D (DDC) at $0.5^{\circ}$ elevation for (a), (b) 1904 and (c), (d) 2036 UTC. Surface observations are overlaid in (a) and (c); Garden City (GCK), Ness City (NES), and Hays (HYS) are highlighted in (b) and (d). Plotting conventions for temperature, dewpoint temperature, wind, the cold front, and the dryline are the same as in Fig. 1. Locations of the dropsondes deployed between 1927-1950 and 2045-2109 UTC are marked by $\times$ signs in (c) and (d). The location of the inner observational domain is highlighted as box B. 
TABLE 1 . Thermodynamic parameters from the Dodge City sounding launched at 1800 and 2100 UTC.

\begin{tabular}{lcc}
\hline \hline & 1800 UTC & 2100 UTC \\
\hline CAPE $\left(\mathrm{J} \mathrm{kg}^{-1}\right)$ & 1915 & 2479 \\
CIN $\left(\mathrm{J} \mathrm{kg}^{-1}\right)$ & 294 & 130 \\
LCL $(\mathrm{km})$ & 2.4 & 2.6 \\
LFC $(\mathrm{km})$ & 4.0 & 3.6 \\
\hline
\end{tabular}

servations collected by instruments on the Naval Research Laboratory (NRL) P3, University of Wyoming (UW) King Air, dropsondes released by the Flight International Lear Jet (LJ), and data collected by the mobile microwave radiometer (MMR) deployed by the Desert Research Institute (DRI). The location of each alongfront NRL P3 flight leg is shown in Fig. 4. The flight track of the UW King Air, locations of dropsondes, and the path of the MMR are also indicated. Time periods and horizontal extent of the airborne data, dropsondes, and microwave radiometer data used for further analysis are listed in Table 2. Spatial extent and resolution in the across-front and vertical directions are summarized in Table 3.

The airborne, dual-beam Electra Doppler radar (ELDORA), the water vapor Differential Absorption lidar (DIAL) Lidar pour l'Etude des Interactions Aerosols Nuages Dynamique Rayonnement et du Cycle de l'Eau (LEANDRE II), and in situ instruments were mounted on the P3 aircraft operated by NRL. The P3 aircraft flew rectangular tracks along and across the cold front between 1830 and 2040 UTC (Fig. 4, Table 2) at an altitude of $\sim 1.3 \mathrm{~km} \mathrm{MSL}^{2}(\sim 0.6 \mathrm{~km} \mathrm{AGL})$. Data obtained during significant aircraft turns, defined as an absolute aircraft roll angle $>5^{\circ}$, were excluded from the analysis to improve the overall accuracy of the Doppler wind retrievals.

Detailed information about the design of ELDORA is provided by Hildebrand et al. $(1994,1996)$. Table 4 lists the specific scanning parameters for the flight. First, ground clutter and data with a low signal-to-noise ratio were eliminated. The fine-tuning navigation correction method was applied to identify and correct uncertainties in the aircraft Inertial Navigation System and errors in the radar-pointing angles (Bosart et al. 2002). Individual fore and aft scans were then interpolated to a three-dimensional Cartesian grid with a horizontal resolution of $600 \times 600 \mathrm{~m}^{2}$ and a vertical resolution of $250 \mathrm{~m}$ using a Cressman (1959) distancedependent weighting scheme. The resolvable

\footnotetext{
${ }^{2}$ In the following sections all heights will be expressed as mean sea level (MSL).
}

wavelength of motion is $\sim 3.6 \mathrm{~km}$ (Carbone et al. 1985). Wind components were derived using a dual-Doppler analysis from the fore and aft scans (Jorgensen et al. 1996). The vertical velocities were derived by integrating the mass continuity equation up- and downward using a variational scheme (O'Brien 1970).

A detailed description of the LEANDRE II can be found in Bruneau et al. (2001). The water vapor mixing ratio is determined from the differences in backscattered laser energy centered on and outside a water vapor absorption band. Configuration characteristics are listed in Table 4. Data were interpolated onto a twodimensional Cartesian grid with a horizontal resolution of $450 \mathrm{~m}$ using a two-pass Barnes filter (Barnes 1973). LEANDRE II data sampling was limited relative to ELDORA because the lidar was operating in a noneye safe mode. Therefore, the analysis was restricted to two flight legs that had the most complete lidar and radar coverage across the front.

The UW King Air intersected the front 4 times between 2006 and 2053 UTC (dashed red lines in Figs. $4 \mathrm{f}, \mathrm{g}$ ). Each leg of the flight track was about $42 \mathrm{~km}$ long at an altitude of about $0.9,1.05,1.45$, and $1.94 \mathrm{~km}$. Data were recorded at a frequency of $1 \mathrm{~Hz}$, resulting in a spatial resolution of about $90 \mathrm{~m}$, given an average aircraft speed of $90 \mathrm{~m} \mathrm{~s}^{-1}$.

Eighteen global positioning system dropsondes (Väisälä model RD93) were deployed from LJ flying across the cold front from northwest to southeast between 1927-1950 (Figs. 3c and 4d) and 2045-2109 UTC (Figs. 3d and 4g). Data were sampled every $0.5 \mathrm{~s}$, which corresponds to a vertical resolution of about $8 \mathrm{~m}$ when assuming a dropsonde fall speed of $16 \mathrm{~m} \mathrm{~s}^{-1}$.

Integrated water vapor measurements were provided by a MMR deployed by the DRI (Fig. 4). The MMR is a dual-channel instrument that operates at frequencies of 20.6 and $31.65 \mathrm{GHz}$ (Huggins 1995). Its zenithpointing antenna yields a $2.5^{\circ}$ beam sampling width. Statistical retrieval techniques are used to compute path-integrated depths of water vapor and liquid water (Westwater and Strand 1972; Hogg et al. 1983).

\section{The observed across-front variability}

\section{a. Dropsonde analysis}

The first series of dropsondes was placed across the cold front from northwest to southeast between 1927 and 1950 UTC in an area where there was no clear evidence of the dryline based on radar reflectivity (Fig. 4d). Vertical cross sections derived from profiles of temperature, mixing ratio, and wind are shown in Fig. 5. The northwestern part of the traverse observed between 1927 and 1939 UTC passed through the cool sec- 


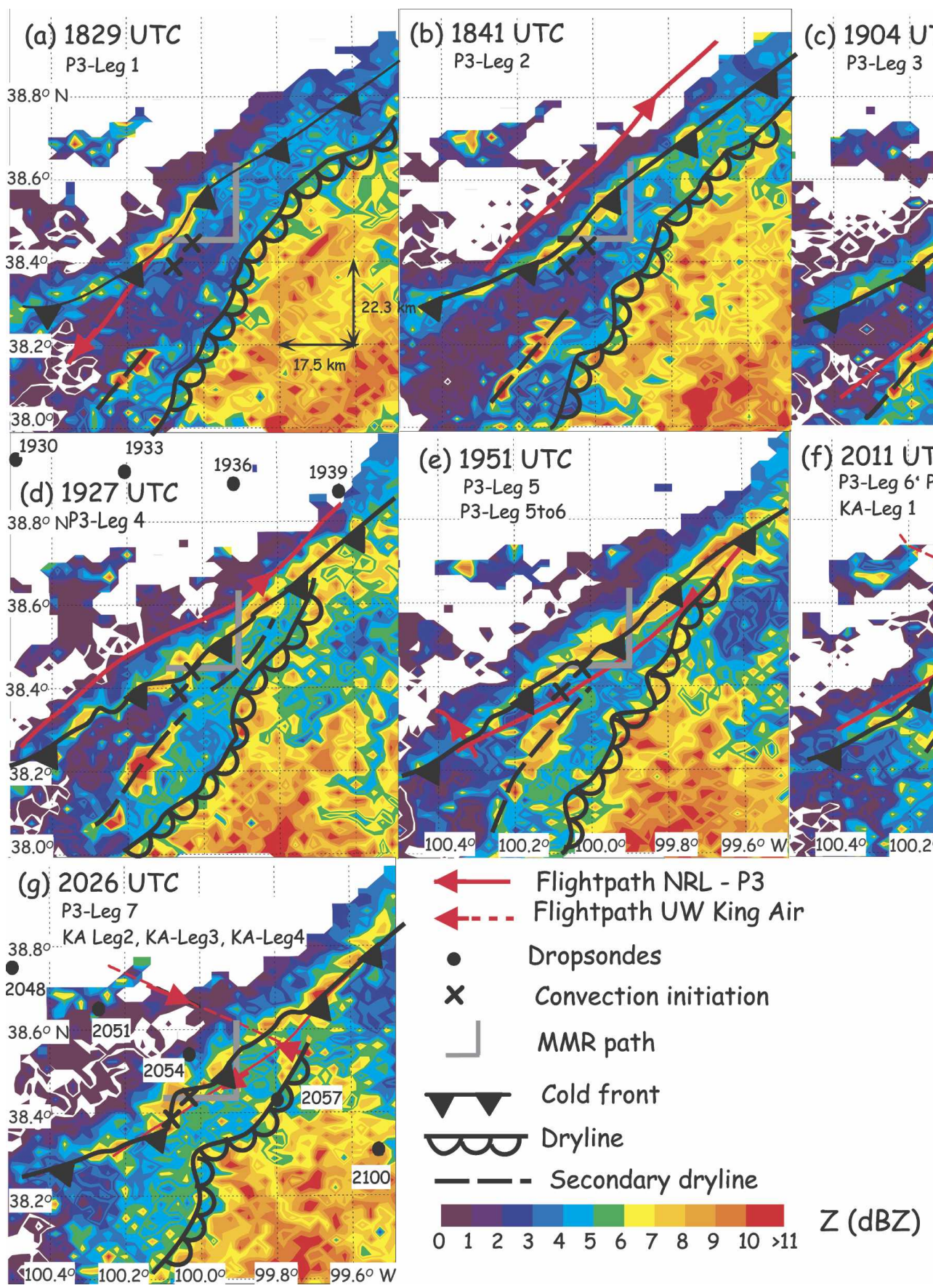

FIG. 4. Horizontal cross sections of the color-coded DDC radar reflectivity (scale at the bottom) at $1.5 \mathrm{~km}$ MSL between 1829 and 2026 UTC within the inner observational domain labeled as box B in Figs. 2 and 3. The flight path and direction are indicated as (a)-(g) solid red lines for the NRL-P3 aircraft and as (f) and (g) dashed red lines for the UW King Air aircraft. The path of the MMR is depicted by solid gray lines in (a)-(g). Locations of dropsondes deployed between 1930-1939 and 2048-2100 UTC are indicated by dots in (d) and $(\mathrm{g})$. Two convective cells were first observed by radar at the locations marked by the $\times$ signs. Plotting conventions for the cold front and dryline are the same as in Fig. 2. Times at the top correspond to the analysis times of the DDC radar. Time periods and lengths of the airborne data are the same as listed in Table 2. 
TABLE 2. List of the analyzed flight legs and radiometer sections: leg name, leg duration, leg length, and leg directional orientation (presented in sets of two rows) of the NRL-P3 (P3), the UW King Air aircraft (KA), the Flight International Lear Jet (LJ), and the MMR truck.

\begin{tabular}{|c|c|c|c|c|c|c|c|}
\hline \multicolumn{2}{|c|}{ NRL-P3 } & \multicolumn{2}{|c|}{ UW KA } & \multicolumn{2}{|c|}{ LJ } & \multicolumn{2}{|c|}{ MMR } \\
\hline Name & Time (UTC) & Name & Time (UTC) & Name & Time (UTC) & Name & Time (UTC) \\
\hline Heading & Length (km) & Heading & Length (km) & Heading & Length (km) & Heading & Length $(\mathrm{km})$ \\
\hline P3-Leg1 & $1831-1837$ & & & & & MMR-Leg1 & $1829-1839$ \\
\hline NE-SW & 42 & & & & & E-W & 17 \\
\hline P3-Leg2 & $1844-1856$ & & & & & MMR-Leg2 & 1839-1911 \\
\hline SW-NE & 116 & & & & & $\mathrm{~W}-\mathrm{E}$ & 17 \\
\hline P3-Leg3 & 1902-1920 & & & & & MMR-Leg3 & 1912-1926 \\
\hline NE-SW & 123 & & & & & $\mathrm{E}-\mathrm{W}$ & 17 \\
\hline P3-Leg4 & 1929-1944 & & & LJ-Leg1 & 1927-1950 & MMR-Leg4 & 1926-1947 \\
\hline SW-NE & 100 & & & NW-SE & 200 & $\mathrm{~W}-\mathrm{E}$ & 17 \\
\hline P3-Leg5 & 1951-2005 & & & & & MMR-Leg5 & 1947-2003 \\
\hline NE-SW & 100 & & & & & E-W & 17 \\
\hline P3-Leg5-6 & 2007-2008 & KA-Leg1 & 2006-2022 & & & MMR-Leg6 & 2004-2018 \\
\hline SE-NW & 15 & SE-NW & 42 & & & $\mathrm{~W}-\mathrm{E}$ & 17 \\
\hline P3-Leg6 & 2011-2023 & KA-Leg2 & 2023-2033 & & & & \\
\hline SW-NE & 73 & NW-SE & 42 & & & & \\
\hline P3-Leg6-7 & $2025-2027$ & KA-Leg3 & 2036-2043 & & & MMR-Leg7 & 2038-2050 \\
\hline NW-SE & 16 & SE-NW & 42 & & & $\mathrm{~S}-\mathrm{N}$ & 22 \\
\hline P3-Leg7 & 2029-2041 & KA-Leg4 & 2045-2053 & LJ-Leg2 & 2045-2109 & MMR-Leg8 & $2051-2105$ \\
\hline \multirow[t]{3}{*}{ NE-SW } & 77 & NW-SE & 42 & NW-SE & 200 & $\mathrm{~N}-\mathrm{S}$ & 22 \\
\hline & & & & & & MMR-Leg9 & $2106-2120$ \\
\hline & & & & & & $\mathrm{S}-\mathrm{N}$ & 22 \\
\hline
\end{tabular}

tor behind the cold front while the leading edge of the front was intersected between 1939 and 1942 UTC. The cool sector extended up to about $2 \mathrm{~km}$ and was characterized by a northwesterly wind $<5 \mathrm{~m} \mathrm{~s}^{-1}$ up to an altitude of $1.5 \mathrm{~km}$ backing to southwest between 1.5 and $2 \mathrm{~km}$. Virtual potential temperatures $\left(\theta_{v}\right)$ ranged from 312 to $316 \mathrm{~K}$ in the cool air mass and were the lowest observed temperatures along this traverse. The mixing ratio $(q)$ within the cool air was less than $10 \mathrm{~g} \mathrm{~kg}^{-1}$ and increased only to $11 \mathrm{~g} \mathrm{~kg}^{-1}$ at the leading edge of the cold front.

The dryline ahead of the cold front is not clearly evident between 1942 and 1950 UTC in Fig. 5 since the air ahead of the front was comparatively moister than the cool air. The mixing ratio increased immediately ahead of the cold front and ranged from 11 to $14 \mathrm{~g} \mathrm{~kg}^{-1}$, with values of equivalent potential temperature $\left(\theta_{e}\right)$ as high as $355 \mathrm{~K}$. However, the relative humidity measurements of the dropsondes launched at both 1945 and 1950 UTC were biased to the point that their thermodynamic data could not be used in the analysis. Therefore, mixing ratio and temperatures were interpolated between 1942 and 1959 UTC (indicated as dashed lines in Fig. 5). Interestingly, a change in wind within the warm, moister air mass was still visible up to $\sim 1.3 \mathrm{~km}$ with southwesterly winds of $<5 \mathrm{~m} \mathrm{~s}^{-1}$ about $20 \mathrm{~km}$ ahead of the cold front, which backed to southerly winds of $\sim 7.5 \mathrm{~m} \mathrm{~s}^{-1}$ about $70 \mathrm{~km}$ farther to the southeast. At the northeastern edge of the observational domain, there are very few surface observations, which

TABLE 3. Spatial extent and resolution of data collected in the across-front, alongfront, and vertical dimensions. Datasets characterized include dropsondes, in situ measurements by the UW King Air, and the NRL-P3, ELDORA, LEANDRE II, and the MMR.

\begin{tabular}{lcccc}
\hline \hline & $\begin{array}{c}\text { Across-front } \\
\text { extent }(\mathrm{km})\end{array}$ & $\begin{array}{c}\text { Vertical } \\
\text { extent }(\mathrm{km})\end{array}$ & $\begin{array}{c}\text { Across-front } \\
\text { resolution }(\mathrm{km})\end{array}$ & $\begin{array}{c}\text { Alongfront } \\
\text { resolution }(\mathrm{km})\end{array}$ \\
\hline Dropsondes & 200 & 4 & 25 & $\begin{array}{c}\text { Vertical } \\
\text { resolution }(\mathrm{m})\end{array}$ \\
In situ at UW King Air & 42 & 1 & 0.09 & 8 \\
ELDORA & 30 & 2.5 & 0.6 & 0.6 \\
MMR & 22 & & 0.2 & 2500 \\
In situ at P3 LEANDRE II & 20 & & 0.115 & 0.45 \\
& 15 & & 0.45 & \\
\hline
\end{tabular}


TABLE 4. Configuration characteristics of ELDORA and LEANDRE II mounted onto the NRL-P3 aircraft as implemented on 10 Jun 2002. The along-track resolution is based on an average aircraft speed of $\sim 115 \mathrm{~m} \mathrm{~s}^{-1}$.

\begin{tabular}{lc}
\hline \multicolumn{2}{c}{ ELDORA } \\
\hline \multicolumn{2}{c}{ Transmitted frequency } \\
Antenna rotation rate & $75^{\circ} \mathrm{s}^{-1}$ \\
Beamwidth (circular) & $1.8^{\circ}$ \\
Beam tilt angle (fore and aft) & $\pm 18.5^{\circ}$ \\
No. of samples & 60 \\
Pulse repetition frequency & $3000 \mathrm{~Hz}$ \\
Gate length & $110 \mathrm{~m}$ \\
& \\
\hline \multicolumn{1}{c}{ LEANDRE II } & $736.3 \mathrm{~nm}$ \\
$\quad$ absorption band & $10 \mathrm{~Hz}$ \\
Pulse repetition frequency & $\pm 0.5 \mathrm{~g} \mathrm{~kg}$ \\
Accuracy & $10 \mathrm{~s}$ \\
Averaging interval & $300 \mathrm{~m}$ \\
Along-beam resolution & $1.2 \mathrm{~km}$ \\
Along-track resolution & \\
\hline
\end{tabular}

leads to speculation about whether the hot, dry air extended that far northeast or if the warm, moister air had already merged with the cold front. Although the winds show the typical signature associated with the hot, dry air at 1942 UTC, the mixing ratio values (11-14 $\mathrm{g} \mathrm{kg}^{-1}$ ) sampled by the dropsondes inclusively between 1942 and 1950 UTC indicate the existence of a moist air mass. Since signatures of the hot, dry air were measured, it is most likely that the warm, moister air has already merged with the hot, dry air in the northeastern part of the observational domain.

Large increases of $\theta_{v}$ and decreases of $\theta_{e}$ with increasing altitude indicate the existence of a statically very stable and convectively very unstable layer above the cool air mass at $\sim 2-2.5 \mathrm{~km}$ MSL and above the warm, moister air mass at $\sim 2.3-3 \mathrm{~km}$ MSL. Below the capping layer, both air masses were neutrally stratified. Above the capping layer, a stable layer existed with winds from the southwest at speeds of $5-10 \mathrm{~m} \mathrm{~s}^{-1}$.

About an hour later, a second series of dropsondes was placed across the cold front from northwest to southeast (Figs. 3c,d and $4 \mathrm{~g}$ ). Subsequent dropsondes along the line were released farther to the south than those in the first series. A vertical cross section through the cold front is shown in Fig. 6. The cool air sector was still located to the northwest and was intersected between 2045 and 2054 UTC. The leading edge of the front was crossed between 2054 and 2057 UTC. Compared to the first series of dropsondes (1927-1939 UTC in Fig. 5), $\theta_{v}$ within the cool air sector increased by $\sim 3$ $\mathrm{K}$ as a result of daytime heating. The front still extended up to $\sim 2 \mathrm{~km}$ and was characterized by westerly to northwesterly winds of $5-10 \mathrm{~m} \mathrm{~s}^{-1}$. Drying was also evident in the cool sector, as mixing ratio $(q)$ decreased by $\sim 1 \mathrm{~g} \mathrm{~kg}^{-1}$ between the first and the second traverses across the cold front. The vertical profile of mixing ratio at the cold front leading edge (2054 UTC) shows a pronounced moisture bulge between $\sim 2.3$ and $3 \mathrm{~km}$ MSL. Note that this dropsonde was released close to the point where two convective cells were first observed by the DDC radar after 2100 UTC. Similar vertically oriented moisture bulges have been observed along drylines (Schaefer 1974, 1986; Ziegler and Hane 1993; Ziegler and Rasmussen 1998; Murphey et al. 2006) and have been hypothesized to indicate convergence and upward motion of a deep layer.

Southeast of the cold front, the second series of dropsondes sampled a region where the front and the warm, moister air advected from the south were still separated by hot, relatively dry air advected from the southwest. The dryline was intersected by this dropsonde transect at $\sim 2057$ UTC. The hot, dry air was characterized by $\sim 3 \mathrm{~g} \mathrm{~kg}^{-1}$ lower mixing ratios and $\sim 1-3-\mathrm{K}$ higher virtual potential temperatures than those observed farther to the southeast. Winds from the south-southwest at $\sim 5$ $\mathrm{m} \mathrm{s}^{-1}$ were in evidence. The hot, dry air with mixing ratios $<10 \mathrm{~g} \mathrm{~kg}^{-1}$ extended vertically up to $\sim 1.5 \mathrm{~km}$. The warm, moister air was sampled by dropsondes from 2100 to 2109 UTC and was characterized by stronger winds from the south at about $7.5 \mathrm{~m} \mathrm{~s}^{-1}$ and mixing ratios of $\sim 12-14 \mathrm{~g} \mathrm{~kg}^{-1}$. The virtual potential temperature $\theta_{v}$ was $\sim 1-2 \mathrm{~K}$ higher compared to values observed during the first dropsonde series. The profile of $\theta_{e}$ in this air mass suggests that it was convectively unstable (Fig. 6b).

The second series of dropsondes was associated with a weakening of the strong stable layer over the cool, moist air as a result of daytime heating that was evidenced by decreased vertical gradients of $\theta_{v}$ and $\theta_{e}$ between an altitude of 2 and $3 \mathrm{~km}$. CIN derived from the DDC radiosondes located within the warm, moister air decreased from 294 to $130 \mathrm{~J} \mathrm{~kg}^{-1}$ during the period from 1800 to 2100 UTC (Table 1). The weakening of the capping layer and the heating of the air below created a more favorable environment for thunderstorm development. The air mass above the capping layer was still stably stratified.

\section{b. UW King Air in situ analysis}

Figure 7 shows contoured $\theta_{v}$ and $\theta_{e}$ along a vertical cross section oriented from west-northwest to eastsoutheast from the UW King Air aircraft data (Figs. $4 \mathrm{f}, \mathrm{g})$. Horizontal profiles of wind and mixing ratio along this vertical cross section are depicted in Figs. 8 and 9. 


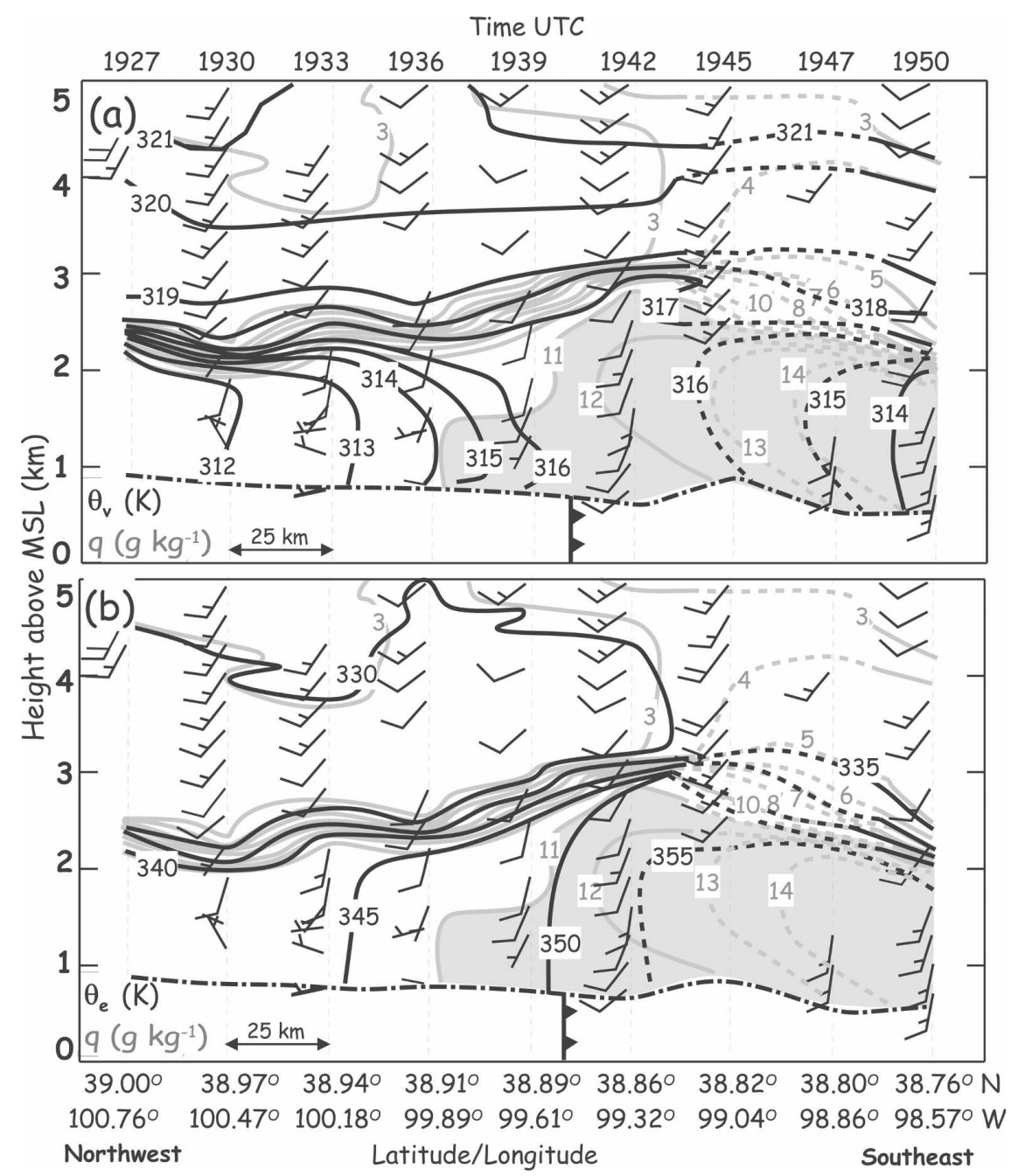

FIG. 5. Northwest-southeast vertical cross section across the cold front based on nine 25-km-spaced dropsondes deployed from the Flight International Lear Jet between 1927 and 1950 UTC. (a) Contours of virtual potential temperatures $\left(\theta_{v}\right)$ and mixing ratio $(q)$, drawn as solid black and gray lines, respectively, are shown along with winds (half barb is $2.5 \mathrm{~m} \mathrm{~s}^{-1}$ and full barb is $5 \mathrm{~m} \mathrm{~s}^{-1}$ ). (b) Same as in (a), but with contours of equivalent potential temperature $\left(\theta_{e}\right)$ instead of $\theta_{v}$. In both (a) and (b), a mixing ratio $>11 \mathrm{~g} \mathrm{~kg}^{-1}$ is shaded gray. The ground level is shown by dash-dot black lines. The gray and black dashed lines indicate the regions where extended interpolation of $\theta_{v}, \theta_{e}$, and $q$ was required due to relative data sparsity that resulted from erroneously biased relative humidity measurements that could not be used for the analysis. The approximate location of the surface cold front is indicated by the black line below ground level with filled triangles.

The cool air sector located to the west-northwest was intersected along $24 \mathrm{~km}$ of the flight segment. Within this area, $\theta_{v}(\sim 316-317.5 \mathrm{~K})$ and $\theta_{e}(347-349 \mathrm{~K})$ were comparable to the values measured by the dropsondes at 2051 and 2057 UTC (Fig. 6). The cool air mass was neutrally stratified throughout the full depth of the UW King Air observations as seen in the $\theta_{v}$ and $\theta_{e}$ fields (Fig. 7). However a change in wind direction at the front from $\sim 300^{\circ}$ to $200^{\circ}$ was observed at 0.9 and 1.2 $\mathrm{km}$, with persistent $250^{\circ}-300^{\circ}$ winds well behind the front (Fig. 8). At $1.5 \mathrm{~km}$ MSL, there was a similar wind shift at the front, but it was less consistent than what was observed at lower altitudes. At $1.8 \mathrm{~km}$, there was a smaller wind shift at the front $\left(\sim 250^{\circ}-200^{\circ}\right)$ that was not sustained at all behind the front. This distribution of wind with height suggests the existence of a shear layer between 1.2 and $1.8 \mathrm{~km}$ within the cool air sector. The mixing ratio within the cool air increased steadily toward the cold front leading edge from $\sim 11$ to $\sim 12 \mathrm{~g} \mathrm{~kg}^{-1}$ (Fig. 9). Vertical velocities ranged between $\pm 2 \mathrm{~m} \mathrm{~s}^{-1}$. 


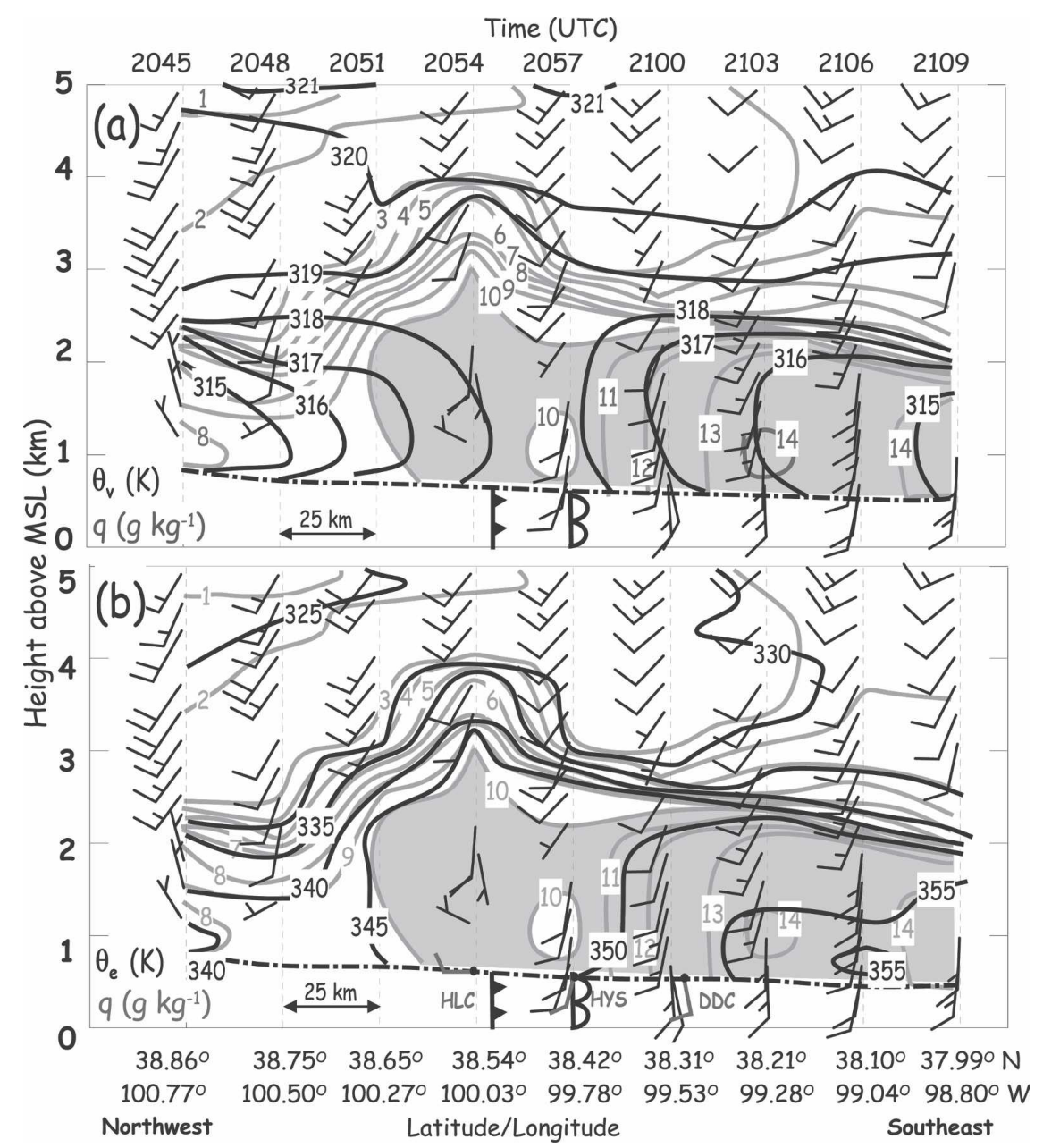

FIG. 6. Same as in Fig. 5, but for dropsondes deployed between 2045 and 2109 UTC. (b) The surface wind measurements at Hill City (HLC), Hays (HYS), and Dodge City (DDC) for 2100 UTC are indicated in gray. A mixing ratio $>10 \mathrm{~g} \mathrm{~kg}^{-1}$ is shaded gray. The dryline is indicated as black line with unfilled semicircles attached.

While the dropsonde released at 2057 UTC only hinted at the existence of hot, dry air immediately ahead of the cold front, much more moisture and wind structure detail is revealed by the horizontal profiles from the UW King Air. The distribution of mixing ratio in Fig. 9 shows that the dry air was characterized by mixing ratios of $\sim 9.8-11.5 \mathrm{~g} \mathrm{~kg}^{-1}$ that reached up to $\sim 1.5 \mathrm{~km}$, with the largest values located between 0.9 and $1.2 \mathrm{~km}$. The dry air was $\sim 5 \mathrm{~km}$ in width at $0.9 \mathrm{~km}$ and increased to $\sim 10 \mathrm{~km}$ at $1.5 \mathrm{~km}$. Again, $\theta_{e}(\sim 346-$ $349 \mathrm{~K}), \theta_{v}(\sim 317.5-318 \mathrm{~K})$, and mixing ratio (9.8-11.5 g $\mathrm{kg}^{-1}$ ) agree well with the dropsonde data measured at 2057 UTC (Fig. 6). This air mass was neutrally stratified (Fig. 7a) but convectively stable (Fig. 7b). Winds in this air mass were directed out of the south-southwest at 8-10 $\mathrm{m} \mathrm{s}^{-1}$ (Fig. 8).

Pronounced changes in wind speed $\left(\sim 7 \mathrm{~m} \mathrm{~s}^{-1}\right)$ and direction $\left(\sim 100^{\circ}\right)$ were observed at the leading edge of the cold front up to $\sim 1.5 \mathrm{~km}$. The slope toward the cool air was about $1 \mathrm{~km}$ up for every $8 \mathrm{~km}$ in the horizontal toward the west-northwest corresponding to a slope of $\sim 7^{\circ}$. The largest horizontal gradient of mixing ratio between the cool, moist and hot, dry air was observed close to the surface $(\sim 0.9 \mathrm{~km})$ and decreased rapidly with height. Vertical velocity increased slightly $(\sim 2$ $\mathrm{m} \mathrm{s}^{-1}$ ) at the cold front leading edge with peak values of $\sim 4 \mathrm{~m} \mathrm{~s}^{-1}$.

The warm, moister air mass was intersected farther to the east-southeast between $99.70^{\circ}$ and $99.78^{\circ} \mathrm{W}$ with mixing ratios of about $11.5 \mathrm{~g} \mathrm{~kg}^{-1}$ and stronger winds from the south. This air mass was neutrally stratified (Fig. 7a) but convectively unstable (Fig. 7b). Again, $\theta_{e}(\sim 348-350 \mathrm{~K}), \theta_{v}(>318 \mathrm{~K})$, and mixing ratio $\left(\sim 11-12 \mathrm{~g} \mathrm{~kg}^{-1}\right)$ agree well with the dropsonde data 


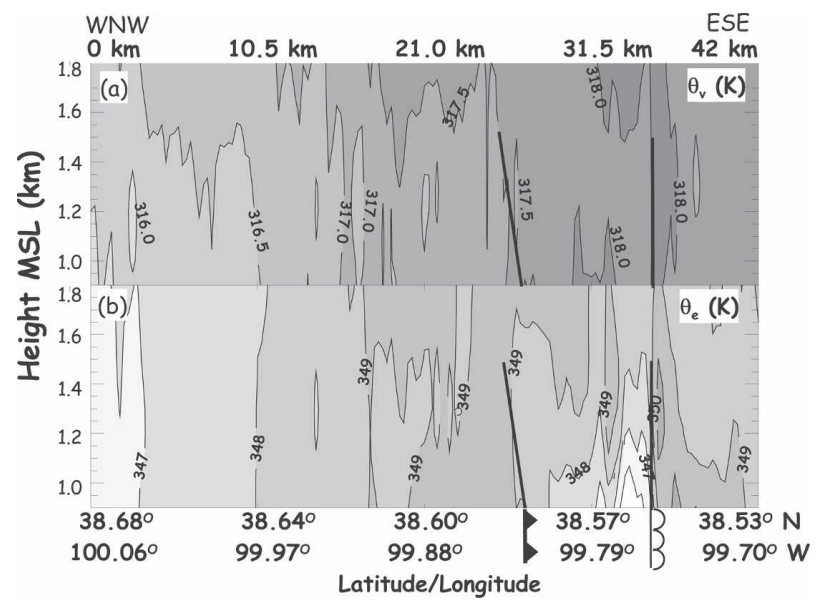

FIG. 7. Vertical cross section of contoured (a) virtual potential temperature $\left(\theta_{v}\right)$ and $(\mathrm{b})$ equivalent potential temperature $\left(\theta_{e}\right)$ from the UW King Air aircraft data at 0.9, 1.1, 1.5, and $1.9 \mathrm{~km}$ MSL between 2006 and 2053 UTC. Darker shades of gray correspond to increasingly larger values of these parameters. The location of this 42-km-long, west-northwest (WNW) to eastsoutheast (ESE) oriented cross section is shown in Figs. 4f,g. The location of the cold front at the surface is indicated by the black line with filled triangle and aloft by the solid black line. The location of the dryline ESE of the cold front is indicated as black line with unfilled semicircles attached and aloft by the solid black line.

measured at 2100 UTC. The dryline separated drier air to the west-northwest from moist air to the eastsoutheast. A pronounced $2 \mathrm{~m} \mathrm{~s}^{-1}$ increase in upward motion relative to surrounding values was only observed along this dryline at $1.5 \mathrm{~km}$. There is no apparent correlation between mixing ratio and vertical velocity (Fig. 9).

\section{c. ELDORA mean vertical cross-section analysis}

Evolution of kinematic structures across the boundaries was investigated by creating a mean vertical cross section. The original coordinate system was rotated in a manner such that its $y^{\prime}$ axis is parallel to and its $x^{\prime}$ axis is perpendicular to the cold front. Mean values were derived from 70 to 207 individual $x^{\prime}$ cross sections of ELDORA data. The averaging process tends to smooth out small-scale variabilities, which results in wind fields that primarily portray larger-scale mean structures that have a horizontal wavelength of $>3.6 \mathrm{~km}$. Based on the evolution of the ELDORA radar reflectivity at $1.5 \mathrm{~km}$ between 1844 and 2041 UTC, the front moved slowly southeastward with an average speed of $\sim 0.9 \mathrm{~m} \mathrm{~s}^{-1}$. Figures 10 and 11 show the evolution of the average front-relative kinematic structure across the front. Since the position of the dryline relative to the front varied in each individual vertical cross section (Figs. 3 and 4 ), the averaging process has smoothed out any kinematic signature of the dryline to the point that it is not evident in the mean cross sections.

A rear-to-front flow of $\sim 2 \mathrm{~m} \mathrm{~s}^{-1}$ was observed behind the cold front almost throughout the entire period. Solely during P3-Leg5 (Fig. 10d) the rear-to-front flow is not shown, which might be related to the fact that area behind and at the cold front was hardly covered by the measurements. Nevertheless, we assume that the rear-to-front flow also existed during this period since it was consistently observed before and after P3-Leg5. Although the lowest ELDORA analysis level was at $1.05 \mathrm{~km}$ it can be assumed that the rear-to-front flow extended down to the ground ( $0.8 \mathrm{~km} \mathrm{MSL})$ based on surface observations. This assumption was confirmed by the observations of Arnott et al. (2006) that indicate front-relative flow in the lowest $500 \mathrm{~m}$ above ground of $5-10 \mathrm{~m} \mathrm{~s}^{-1}$ at 1946 UTC and $<5 \mathrm{~m} \mathrm{~s}^{-1}$ at 2036 UTC. The effect of the rear-to-front flow on the cold frontal structure will be discussed more extensively in section 5. The average kinematic boundary depth, defined as the height between the ground and the zero cold frontrelative velocity, was $\sim 600 \mathrm{~m}$ (Fig. 10). The kinematic boundary depth remained mainly constant with time. We assume that the decrease in the kinematic boundary depth during P3-Leg5 and 7 is primarily due to inadequate sampling of the postfrontal area. At the leading edge of the cold front, isopleths of reflectivity form an upward bulge as indicated by the $-5-\mathrm{dB} Z$ reflectivity contour in Figs. 10 and 11. Above the average kinematic boundary $(>1.3 \mathrm{~km})$ the front-to-rear flow toward the northwest increased with time. Also, the average upward vertical motion at the cold front leading edge increased both in magnitude $\left(0.5\right.$ to $\left.1 \mathrm{~m} \mathrm{~s}^{-1}\right)$ and depth $(1-2 \mathrm{~km})$ during the observation period. During P3-Leg6 and 7, the average positive vertical velocity of $\sim 0.5 \mathrm{~m} \mathrm{~s}^{-1}$ extended up to $3.55 \mathrm{~km}$, reaching the level of free convection located at $\sim 3.6 \mathrm{~km}$ at 2100 UTC.

The upward bulge in reflectivity was collocated with the updraft region shown in Fig. 11. The updraft tilted back over the cool air following the slope of the cold front, which was estimated to be $\sim 7^{\circ}$ in section $4 \mathrm{~b}$. Arnott et al. (2006) showed that the horizontal vorticity within the cool sector is much stronger than the horizontal vorticity ahead of the front, so that the updrafts tilted back over the cool air. As time progressed, the warm, moister air advected from the south, merged with the hot, dry air and converged with the cold front leading edge in the northeastern part of the observational domain. When the average low-level convergence exceeded $\sim 0.5 \times 10^{-3} \mathrm{~s}^{-1}$, the mean updraft increased from $\sim 0.5$ to $1 \mathrm{~m} \mathrm{~s}^{-1}$. With a mean updraft of $1 \mathrm{~m} \mathrm{~s}^{-1}$, a surface parcel needs $\sim 60 \mathrm{~min}$ to reach the LFC. Although an updraft of $\sim 1 \mathrm{~m} \mathrm{~s}^{-1}$ would not ap- 


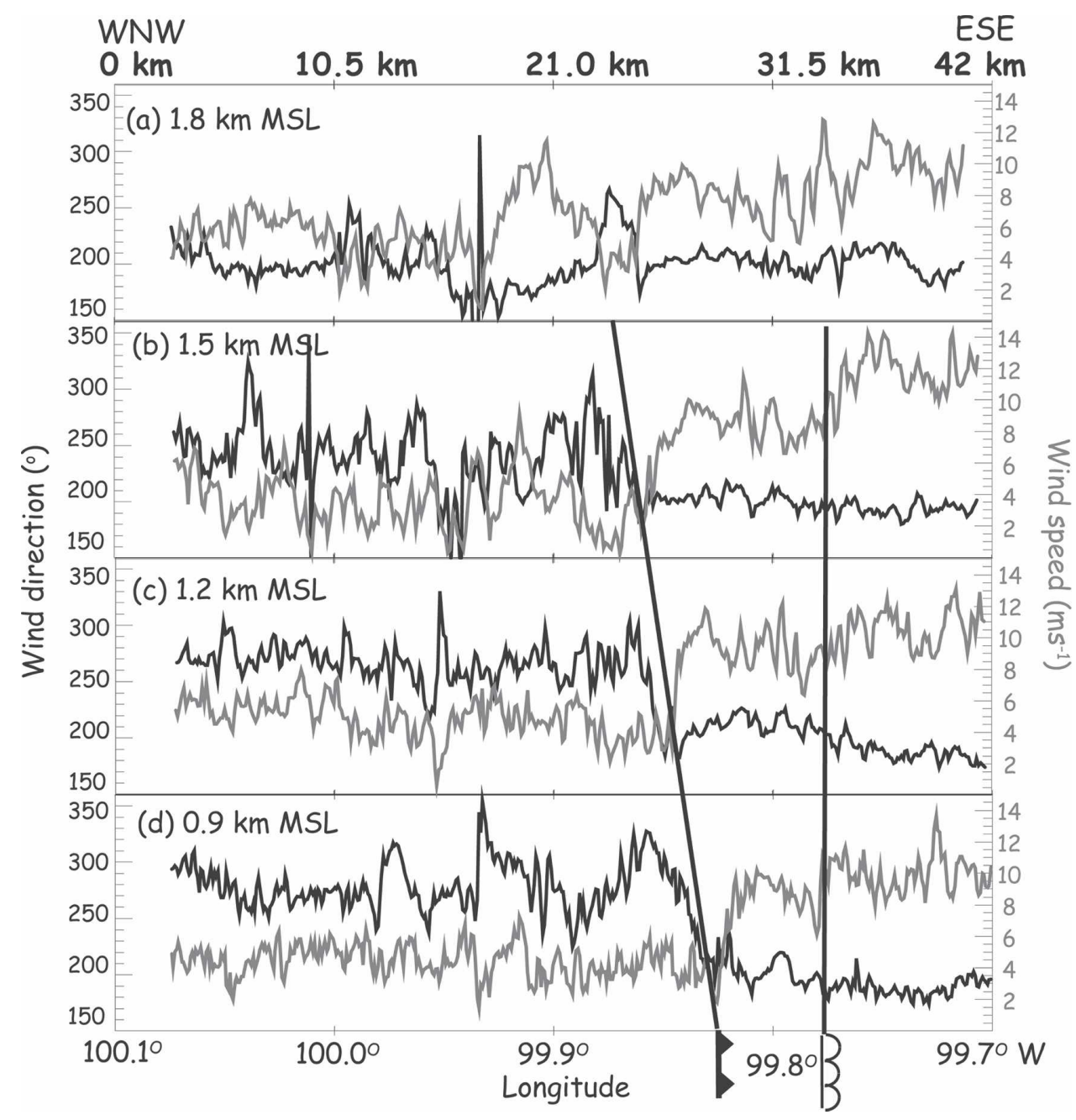

FIG. 8. Same as in Fig. 7, but for horizontal profiles of wind direction (solid black lines) and wind speed (solid gray lines) at each UW King Air flight level.

pear strong enough to initiate convection along an entire cold front, Hobbs et al. (1980) reported heavy precipitation in small areas related to updrafts of $\sim 1 \mathrm{~m} \mathrm{~s}^{-1}$ and convergence values of $\sim 1.9 \times 10^{-3} \mathrm{~s}^{-1}$. Crook and Moncrieff (1988) stated that convection initiation is primarily triggered by strong ascent over a short time or by weak ascent over a longer time, assuming that instability is present. Ziegler et al. (2007) showed that for cumulus cloud development the air parcels need to rise up to their level of free convection before moving laterally out of the updraft region. However, on 10 June the pseudo-dual-Doppler-derived upward motions exceeded $\sim 2-4 \mathrm{~m} \mathrm{~s}^{-1}$ in local areas (figures not shown). With these updraft magnitudes, air parcels need only 15-30 min to reach the LFC. However, air parcels need to remain in the updraft long enough to be lifted to the LFC. Arnott et al. (2006) showed through trajectory analysis that the nearly continuous updraft motion along the cold front and the strong alongfront wind component $\left(\sim 5-6 \mathrm{~m} \mathrm{~s}^{-1}\right)$ between 2 and $4 \mathrm{~km} \mathrm{MSL}$ was a key factor in the development of cumulus clouds along the front prior to 2030 UTC. After 2011 UTC, vertical vorticity maxima $\left(\sim 0.5 \times 10^{-3} \mathrm{~s}^{-1}\right)$ were observed at the cold front leading edge during P3-Leg 6 and 7 (Figs. 11e,f). Arnott et al. (2006) concluded that the vertical vorticity maxima disturb the organized upward motion. When the frontal circulation weakened in the late afternoon, misocyclones have a greater influence on the organization of the vertical velocity than when the frontal circulation was stronger.

\section{d. MMR analysis}

The surface cold front was intersected several times by $20-\mathrm{km}$-wide transects of the MMR monitoring temporal evolution of surface mixing ratio (SMR), integrated water vapor (IWV), and integrated liquid water 


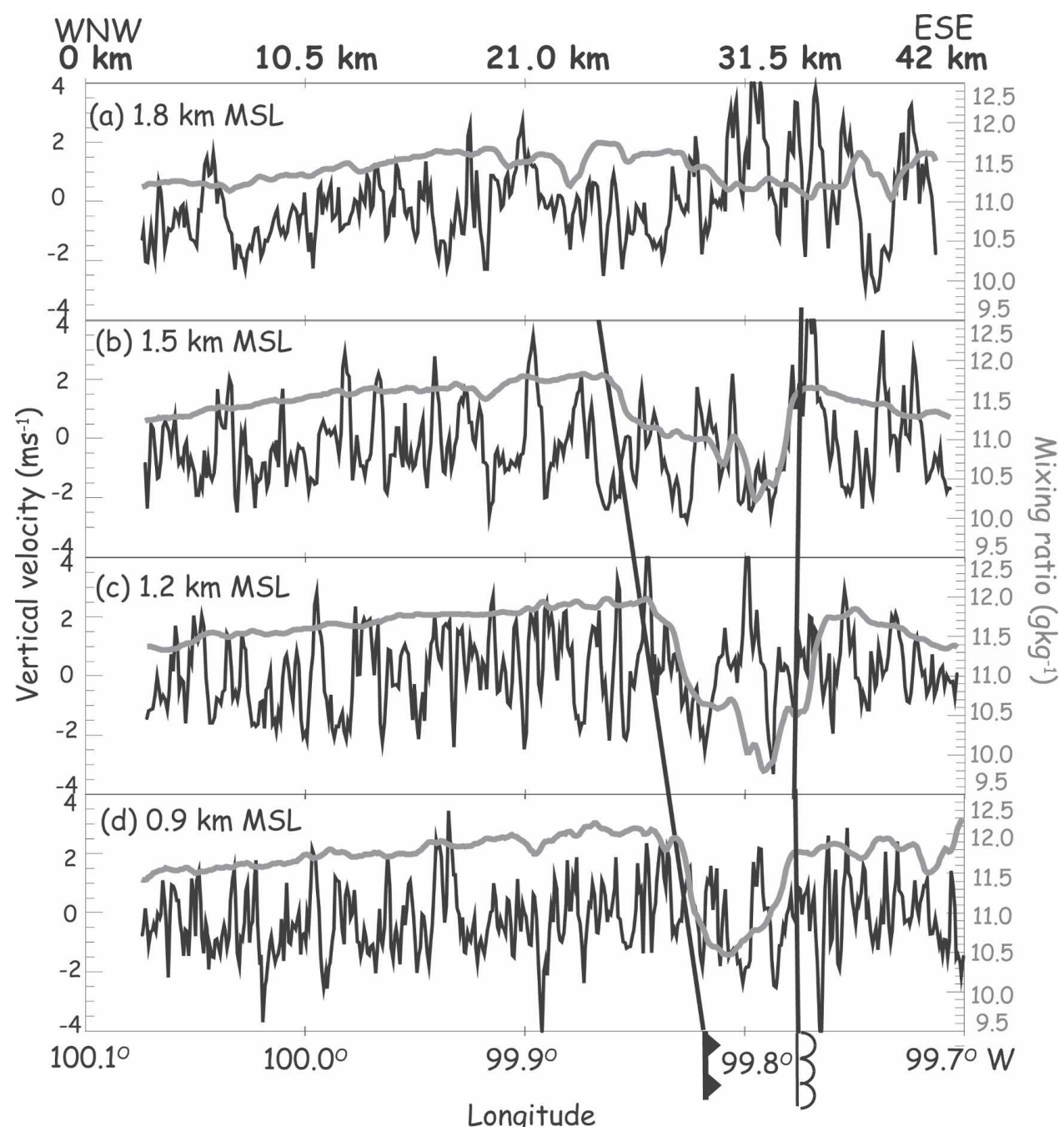

FIG. 9. Same as in Fig. 8, but for horizontal profiles of vertical velocity (solid black lines) and mixing ratio (solid gray lines) at each UW King Air flight level.

(ILW). The first transects (Fig. 12) were directed at a $\sim 50^{\circ}$ angle relative to the orientation of the cold front, while the latter transects (Fig. 13) were executed at a relative angle of $\sim 40^{\circ}$. During MMR-Leg1-4 and MMR-Leg7-9, SMR varied from 7 to $9 \mathrm{~g} \mathrm{~kg}^{-1}$ over the entire transect with no clear distinction in SMR between the post- and prefrontal air (Figs. 12 and 13). However, prefrontal SMR was $\sim 1 \mathrm{~g} \mathrm{~kg}^{-1}$ higher than the postfrontal SMR during MMR-Leg5 and 6 (Figs. 12), which might indicate the arrival of the warm, moister air advected from the south. The IWV increased steadily between 1830 and 2120 UTC over the entire cross section from its average value of $\sim 2.4$ to a maximum of $\sim 3.2 \mathrm{~cm}$. IWV was highly variable across the front with localized maxima exceeding the prefrontal background values by $2-4 \mathrm{~mm}$ between MMR-Leg3 and MMR-Leg6. These maxima occurred every 8-9 km and are indicated by downward-pointing arrows in Fig. 13. Figure 4 shows a line of enhanced reflectivity ahead of the cold front and parallel to the dryline. Arnott et al. (2006) observed open-cell convection and northward-oriented bands of enhanced convergence ahead of the cold front on 10 June 2002. It is possible that the IWV maxima might be manifestations of the enhanced convergence and reflectivity observed ahead of the cold front. A large increase in IWV (to $\sim 3.4 \mathrm{~cm}$ ) was observed after 2051 UTC immediately ahead and behind the cold front leading edge $( \pm 5 \mathrm{~km})$. Radiometric signatures of clouds, defined as locations with ILW $>0.1$ $\mathrm{mm}$, were observed during MMR-Leg5, 6, 8, and 9 (gray-shaded areas in Figs. 12 and 13). They mainly formed within the prefrontal region $\sim 2-10 \mathrm{~km}$ ahead of the cold front leading edge, which is close to the dryline. Clouds were also observed to form $\sim 2-3 \mathrm{~km}$ 
Northwest

Southeast Northwest
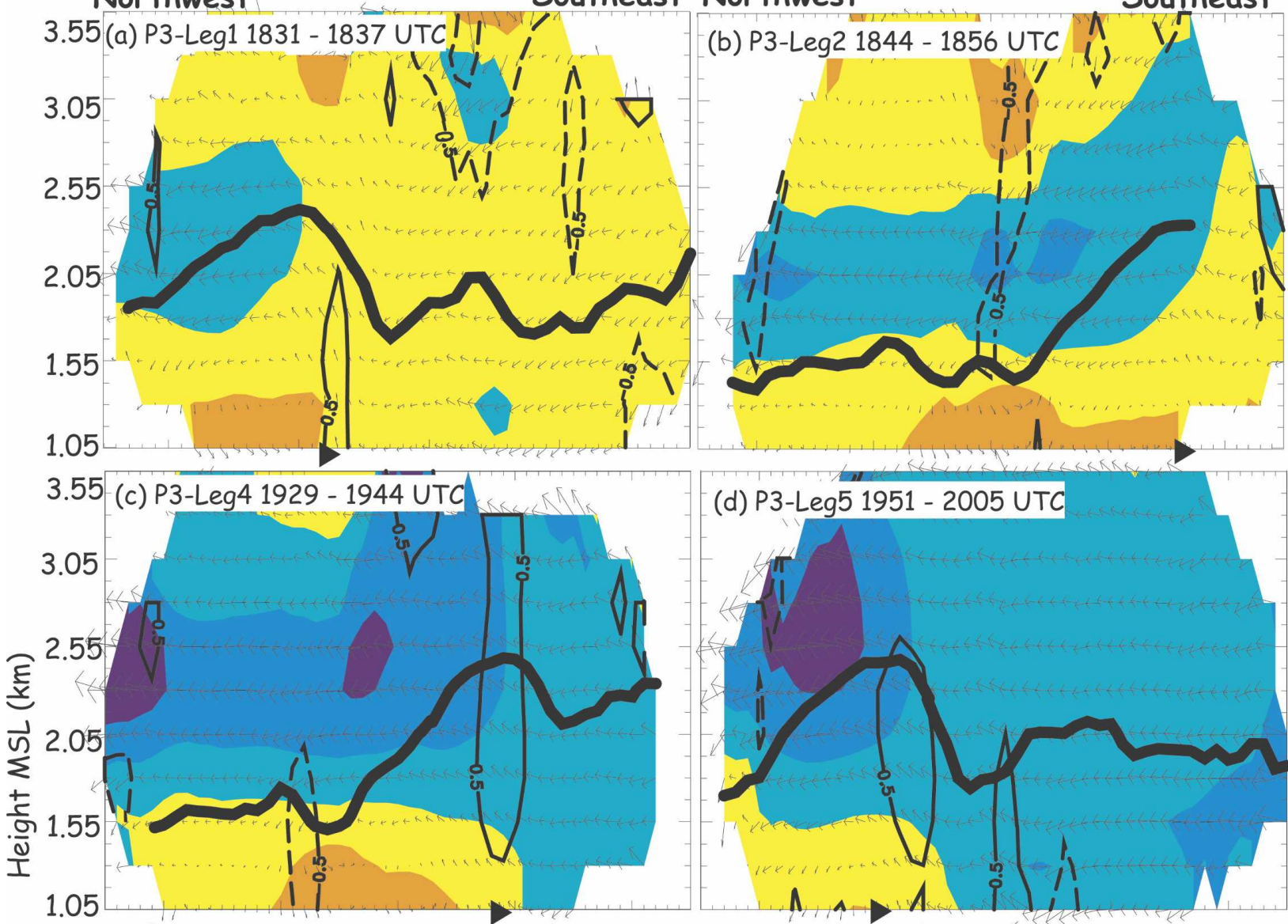

(d) P3-Leg5 1951 - 2005 UTC

$3.55($ e) P3-Leg6 2011 - 2023 UTC
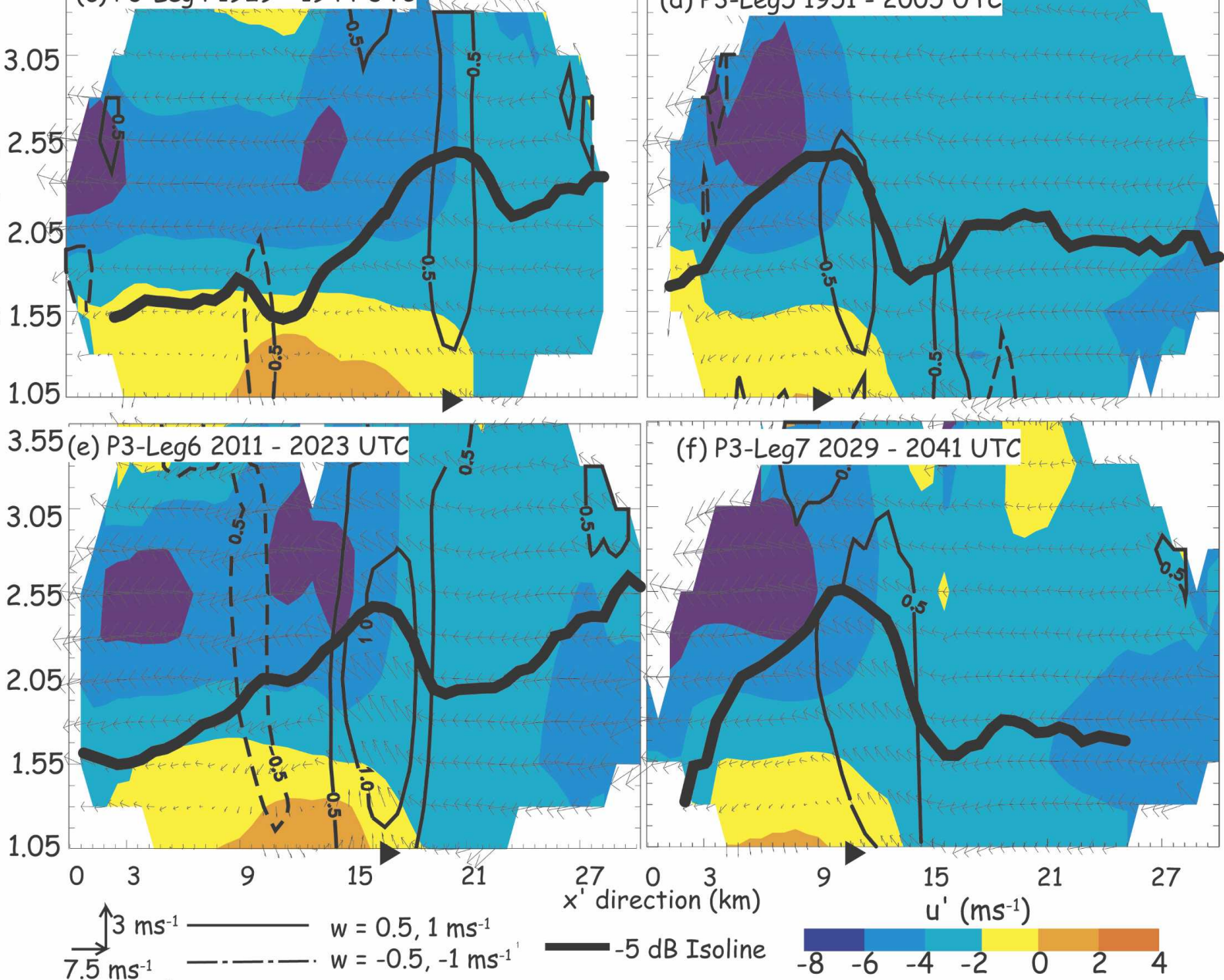

FIG. 10. Mean northwest-southeast vertical cross sections of ELDORA-derived dual-Doppler data across the cold front for (a) P3-Leg1, (b) P3-Leg2, (c) P3-Leg4, (d) P3-Leg5, (e) P3-Leg6, and (f) P3-Leg7. Color-coded front-relative across-front wind component (scale at the bottom) is overlaid by vertical velocity (black lines) and wind vectors (arrows with asymmetric scale indicated) in the plane of the cross sections. Positive (negative) vertical velocity is indicated by solid (dashed) lines. The -5 -dBZ reflectivity contour is highlighted as a thick black line. The position of the reflectivity maxima indicating the approximate location of the surface cold front is indicated by a filled black triangle at the bottom of (a)-(f). 


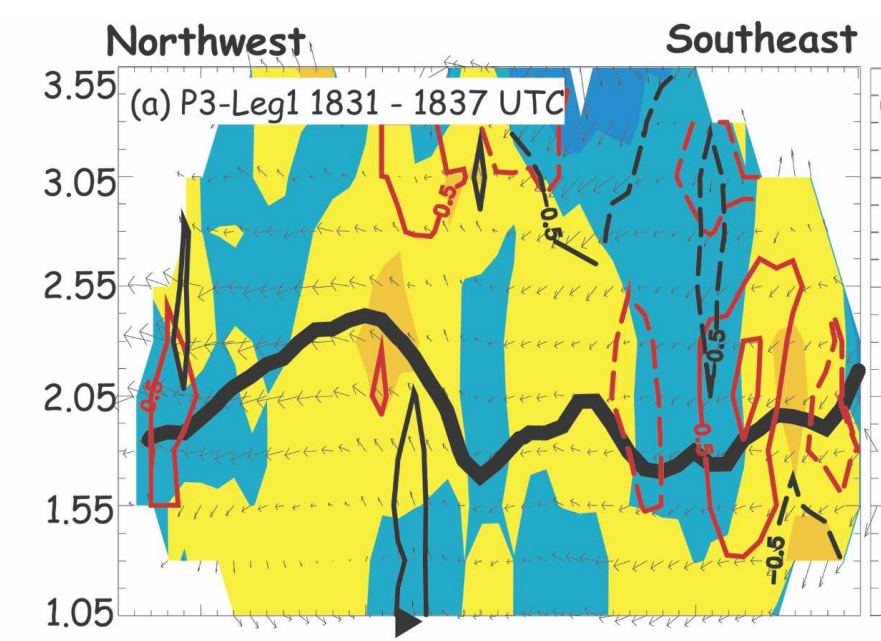

\section{Northwest}

Southeast

(b) P3-Leg2 $1844-1856$ UTC//î
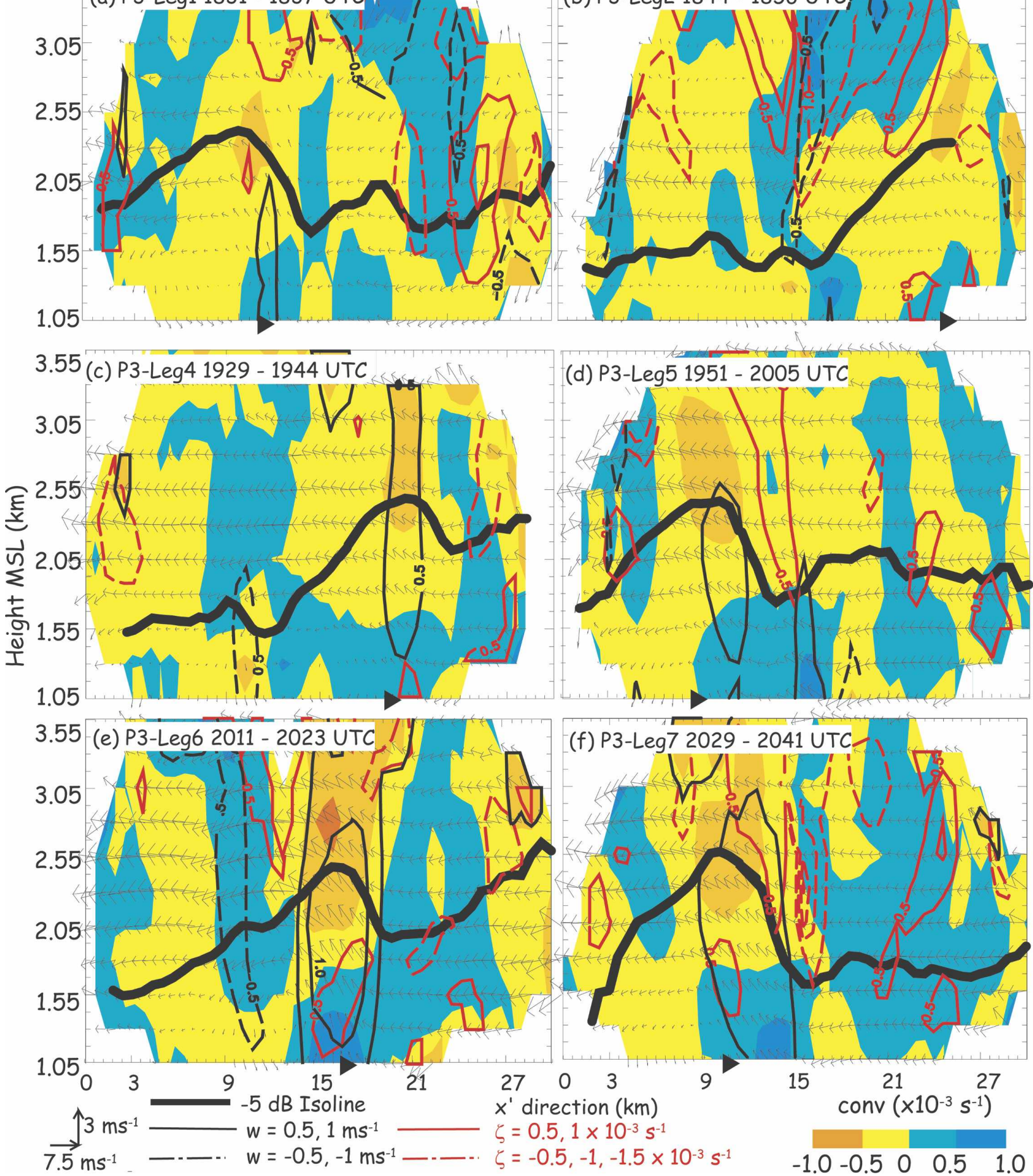

政

FIG. 11. Same as in Fig. 10, but with color-coded convergence field (scale at the bottom) overlaid by vertical velocity (black lines), vertical vorticity (red lines), and wind vectors (arrows with asymmetric scale indicated) in the plane of the cross sections. Positive (negative) vertical velocity and vertical vorticity values are indicated as solid (dashed) lines. 


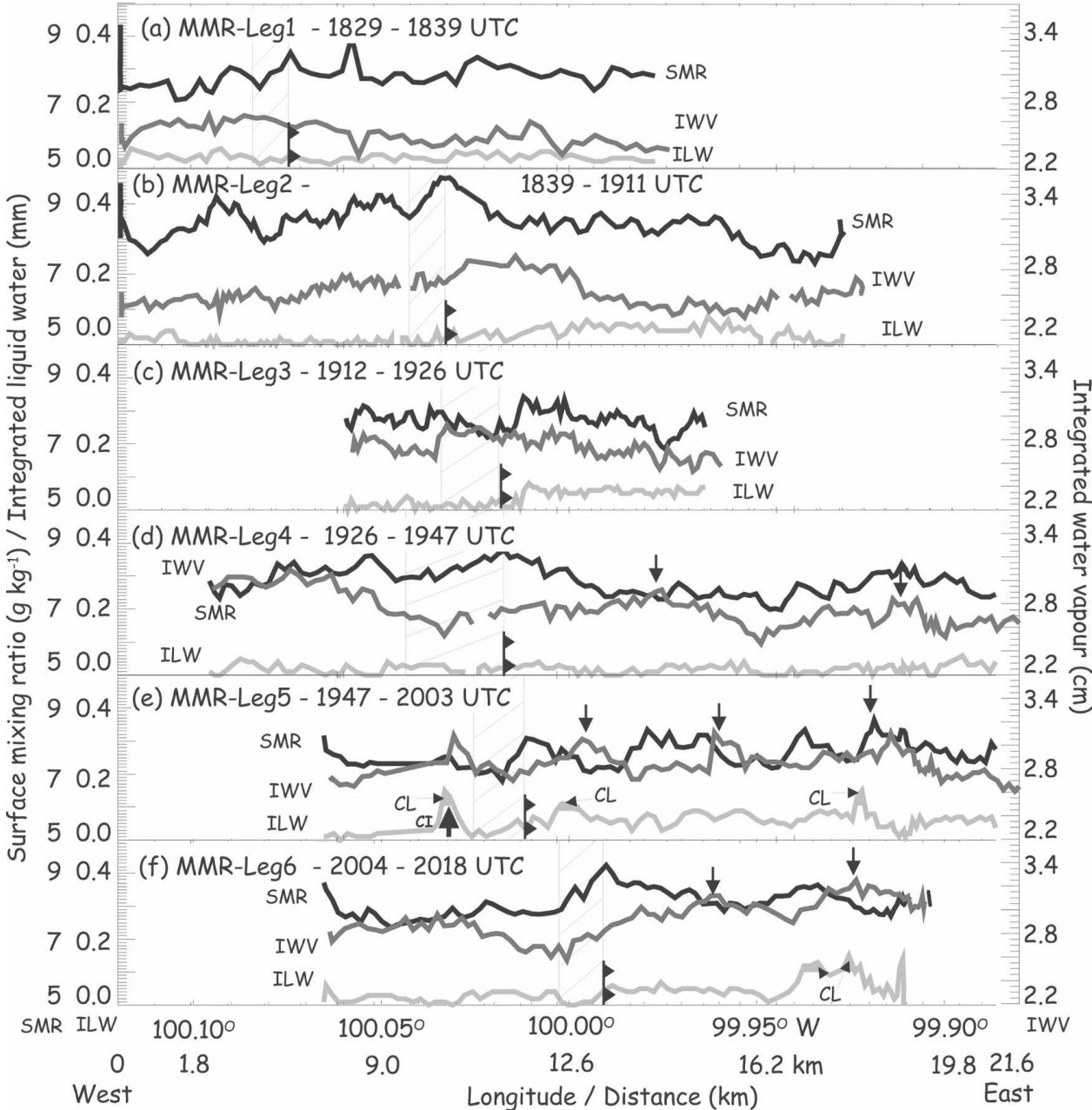

FIG. 12. West-east horizontal profiles of SMR (black lines), IWV (medium gray lines), and ILW (light gray lines) measured by the MMR between 1830 and 2036 UTC (Fig. 4; Table 2). The hatched areas indicate regions with pronounced drops in surface temperature (not shown) from east to west $(\Delta T>2$ $\mathrm{K})$. The location of the cold front is at the eastern extent of these regions and indicated by a black line with filled triangle. Thin, downward-pointing arrows highlight local maxima in IWV. ILW $>0.1 \mathrm{~mm}$, suggestive of the presence of cloud, is shaded gray and labeled as CL. The first convection was observed around the location highlighted by the thick, upward-pointing arrow labeled as CI.

behind the cold front leading edge (gray-shaded areas in Figs. 12e and 13b,c). The formation of clouds within the cool air can be related to the vertical tilt of the cold front.

\section{e. NRL-P3 in situ, ELDORA, and LEANDRE II analysis}

In this subsection the across-front variation of temperature, mixing ratio, and wind measured by NRL-P3 instrumentation is analyzed at $1.3 \mathrm{~km}$ MSL along the southwestern and northeastern ends of the rectangular box pattern executed by the aircraft. The across-front leg on the southwestern end is referred to as P3-Leg5-6, while P3-Leg6-7 corresponds to the across-front leg on the northeastern end. Figure 14 provides an overview of the across-front kinematic and moisture structures observed along these two legs. Since LEANDRE II and P3 in situ measurements across the front were not collocated, the following discussion of these observations is based on a spatial reference along and relative to the beginning of the flight paths shown Fig. 14c for P3Leg5-6 and Fig. 14d for P3-Leg6-7.

The hot, dry air mass was intersected along the southwestern part of the sampling domain during the first 6 $\mathrm{km}$ of P3-Leg5-6 (Figs. 14a,c,e). At the cold front leading edge, LEANDRE II and the P3 in situ measurements observed an increase in mixing ratio from $\sim 9.5$ to $\sim 11.5 \mathrm{~g} \mathrm{~kg}^{-1}$ between 6 and $9 \mathrm{~km}$ of P3-leg5-6 from 


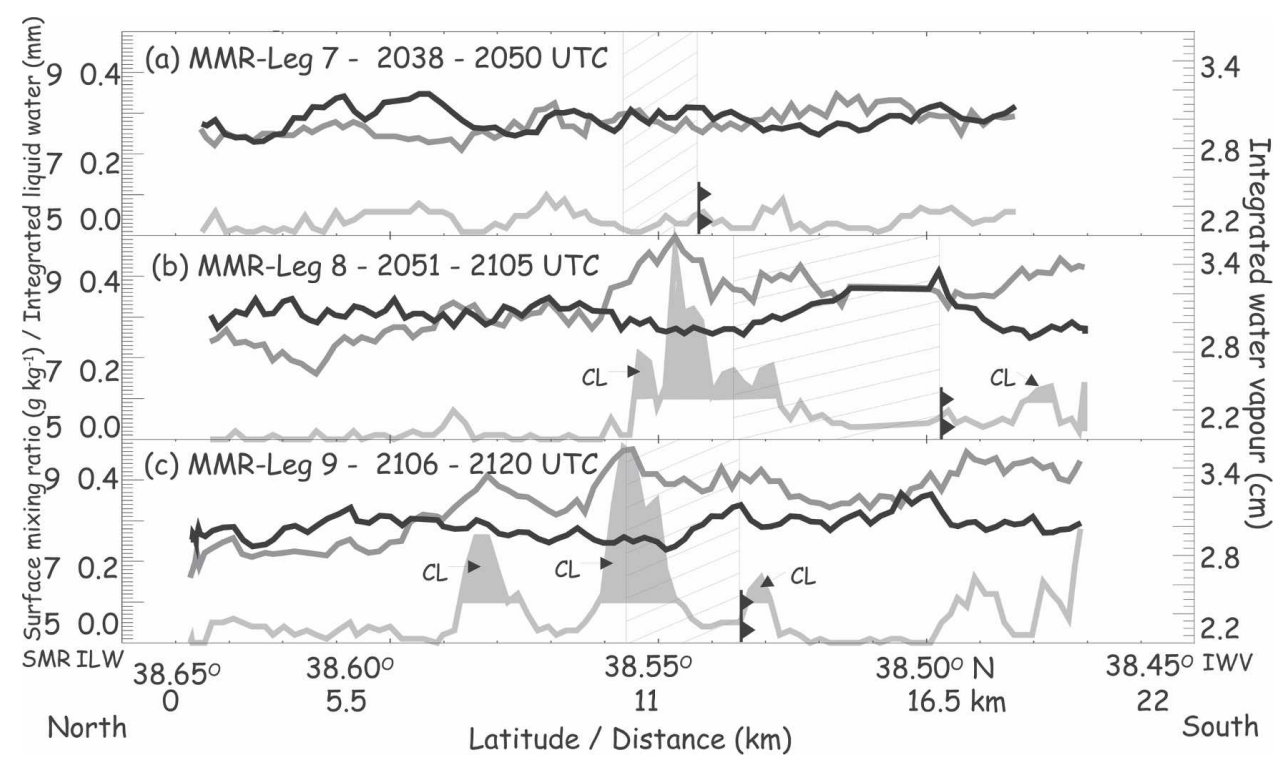

FIG. 13. Same as in Fig. 12, but for north-south horizontal profiles of MMR data between 2038 and 2120 UTC (Fig. 4; Table 2). The location of the cold front is at the southern extent of the pronounced temperature gradient regions that are hatched.

the southeast to the northwest. (Fig. 14e) Within the same distance, $\theta_{v}$ dropped from 318.5 to $317.3 \mathrm{~K}$ (Fig. 14e). A wind shift from southwest to west occurred at $\sim 10 \mathrm{~km}$ along the flight path, immediately behind the drop in $\theta_{v}$ and the increase in mixing ratio. Based on the wind, $\theta_{v}$, and mixing ratio data, the warm, moister air located farther to the southeast, was apparently not sampled during P3-Leg5-6. The P3 aircraft intersected the cool air sector and the wedge of the warm, moister air advected from the south during P3-Leg6-7 along the northeastern end of the sampling domain (Figs. $14 \mathrm{~b}, \mathrm{~d}, \mathrm{f})$. Along this transect, the cool air was encountered between 0 and $11 \mathrm{~km}$ of P3-Leg6-7. At the cold front leading edge at $10-11 \mathrm{~km}$ of P3-Leg6-7, $\theta_{v}$ dropped by $\sim 2 \mathrm{~K}$ and mixing ratio increased slightly by $0.8 \mathrm{~g} \mathrm{~kg}^{-1}$ from southeast to northwest. As observed along the southwestern end during P3-Leg5-6, winds shifted slightly from south to southwest at $10.1 \mathrm{~km}$ along the flight path, immediately behind the drop in $\theta_{v}$ in the cool air sector (Fig. 14f). Contrary to the observations along the southwestern end, the drop in $\theta_{v}$ occurred over a distance of only $\sim 1 \mathrm{~km}$.

Mixing ratios at $1.3 \mathrm{~km}$ MSL were greater (Fig. 14d; 11-14 $\mathrm{g} \mathrm{kg}^{-1}$ ) along the northeastern part of the cold front than along the southwestern part (Fig. 14c; 8-12 g $\left.\mathrm{kg}^{-1}\right)$. The prefrontal difference in moisture is a result of the dry air mass immediately ahead of the cold front to the southwest that is not present to the northeast. The postfrontal differences in moisture are related to differences in the depth of the cold front between the southwest and northeast ends. Along the southwest end, the top of the ELDORA-derived kinematic boundary is at $\sim 1.75 \mathrm{~km}$, whereas the top of the kinematic boundary along the northeast end is at $\sim 1.3 \mathrm{~km}$ (figures not shown). That is, the southwestern flight leg flew within the cool air sector while the northeastern flight leg skimmed the top of the cool air sector. Air transported up and over the cool sector along the northeastern end was relatively moist as a result of the relatively moist prefrontal conditions in that area.

\section{Comparison of cold front to gravity current structures}

Several observational studies suggest that gravity current characteristics are evident along cold fronts. Smith and Reeder (1988) provide an overview of the applicability of gravity current theory to cold fronts. A schematic of the thermal structure and relative flow of an atmospheric gravity current from Smith and Reeder (1988) is illustrated in Fig. 15a. It has been hypothesized that diabatic processes associated with precipitation or the presence of topography are essential to maintain or develop gravity current phenomena. Gravity current characteristics such as a head structure, mixed region, and the jet of cold air propagating faster than the cold front (Fig. 15a) were observed along nonprecipitating cold fronts in the presence of topography (Shapiro 1984; Young and Johnson 1984; Shapiro et al. 

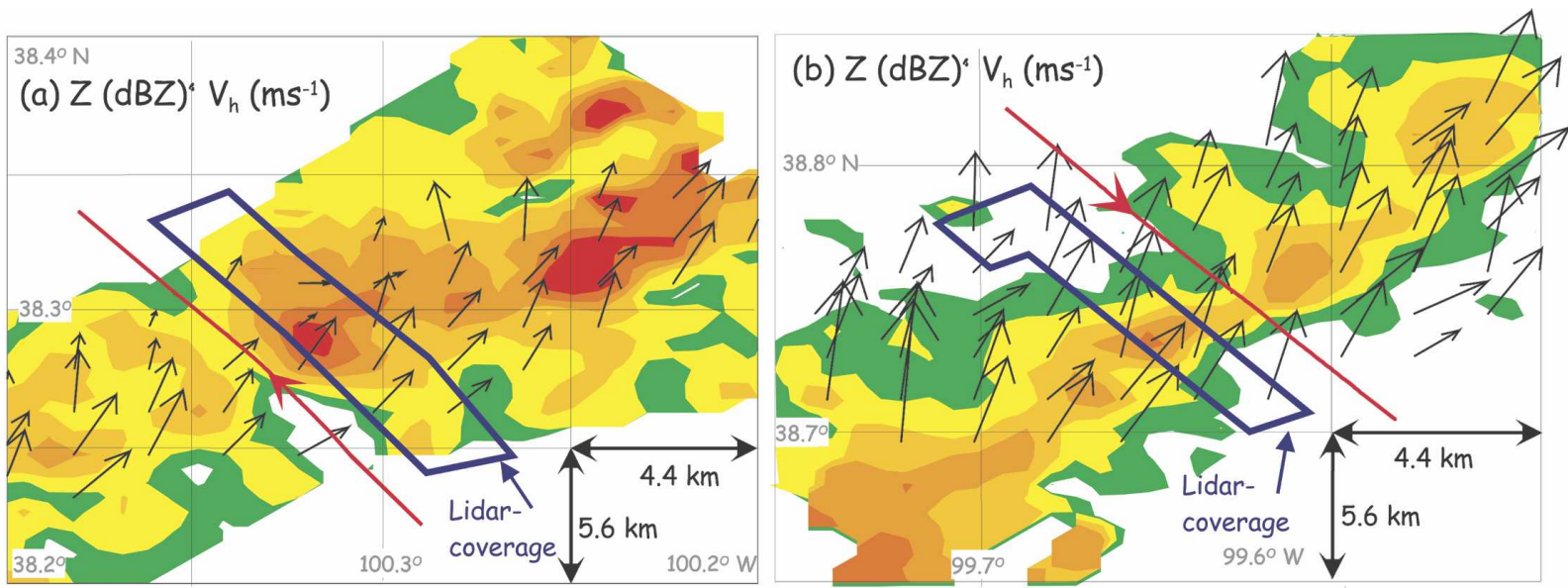

$38.40 \mathrm{~N}$

(c) $q\left(g k g^{-1}\right)^{c} w\left(m s^{-1}\right)^{c} V_{h}\left(m s^{-1}\right)^{c} Z=0 d B^{\prime}$

(d) $q\left(\mathrm{gkg}^{-1}\right)^{a} \mathrm{w}\left(\mathrm{ms}^{-1}\right)^{4} \mathrm{~V}_{\mathrm{h}}\left(\mathrm{ms}^{-1}\right)^{4} \mathrm{Z}=0 \mathrm{~dB}$

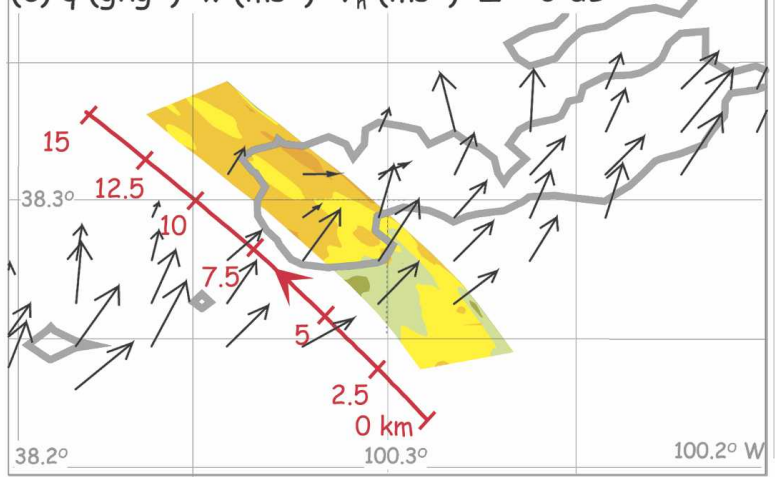

(e) $\theta_{\mathrm{v}}(\mathrm{K}), \mathrm{q}\left(\mathrm{gkg}^{-1}\right), \mathrm{V}_{\mathrm{h}}\left(\mathrm{ms}^{-1}\right)$
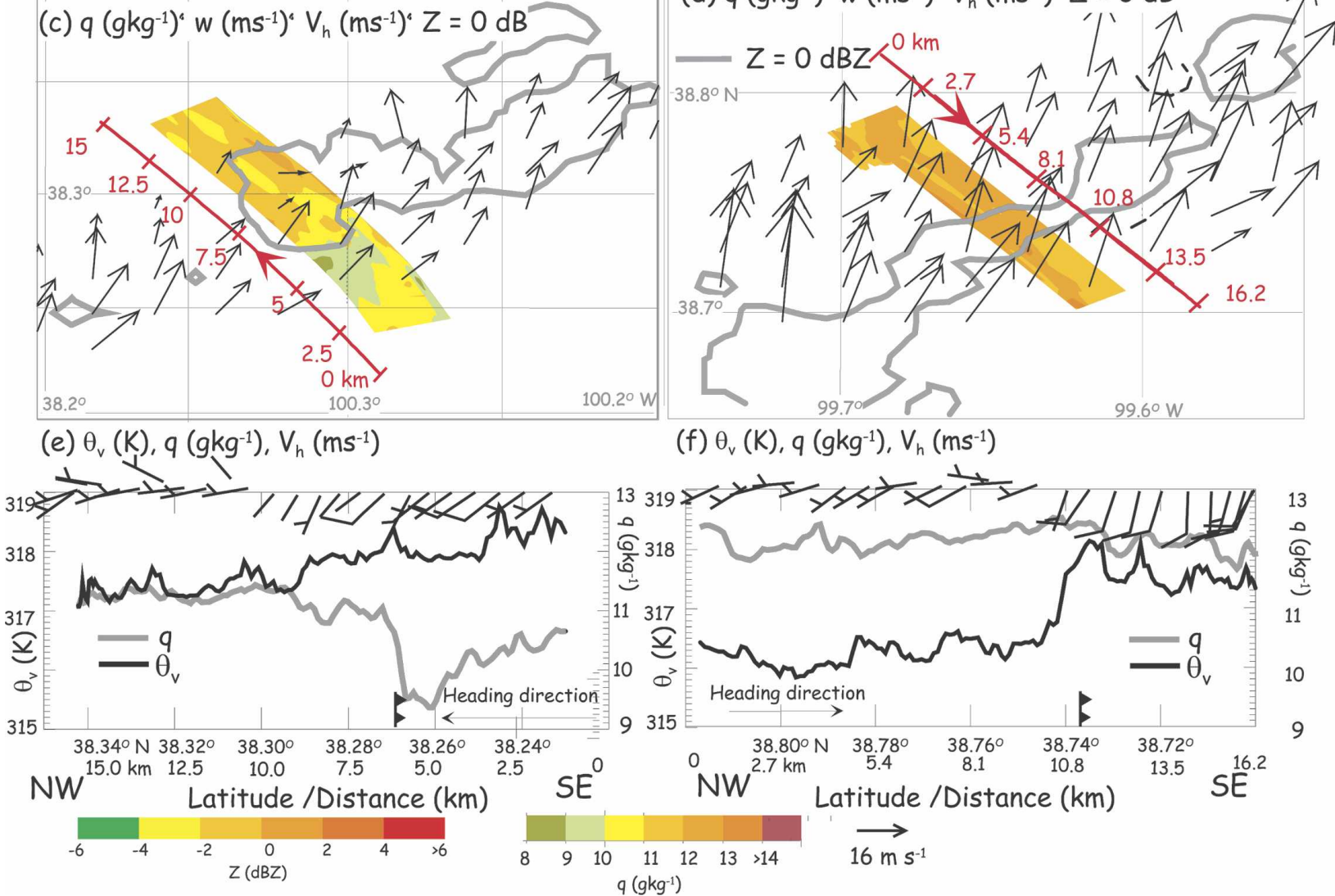

FIG. 14. (a)-(d) The 1.3-km MSL horizontal cross sections of ELDORA-derived dual-Doppler horizontal winds (arrows with scale indicated at bottom): (a), (b) color-coded ELDORA reflectivity and the outer boundaries of the area covered by LEANDRE II (blue box), and (c), (d) color-coded LEANDRE II mixing ratio (scales at the bottom). Location, direction, and length of the NRL-P3-flight legs are indicated by thick red lines with unidirectional arrows. (e), (f) The 1.3-km MSL in situ measurements from the NRL-P3 aircraft of virtual potential temperature $\left(\theta_{v}\right)$ and mixing ratio $(q)$ indicated by black and gray lines, respectively, and horizontal winds (half barb is $2.5 \mathrm{~m} \mathrm{~s}^{-1}$ and full barb is $5 \mathrm{~m} \mathrm{~s}^{-1}$ ). The approximate location of the surface cold front is indicated at the bottom of the plots by the black line with the filled triangle.

1985). Several other studies showed that neither topography nor precipitation processes are necessary to trigger these gravity current characteristics (e.g., Clarke 1961; Garratt and Physick 1986; Brandes and Rabin
1991; Bond and Shapiro 1991; Geerts et al. 2006). Most of the recent studies on the applicability of gravity current theory to cold fronts were conducted on fastmoving fronts; the relevance of the theory for slow- 
(a) Gravity Current Schematic
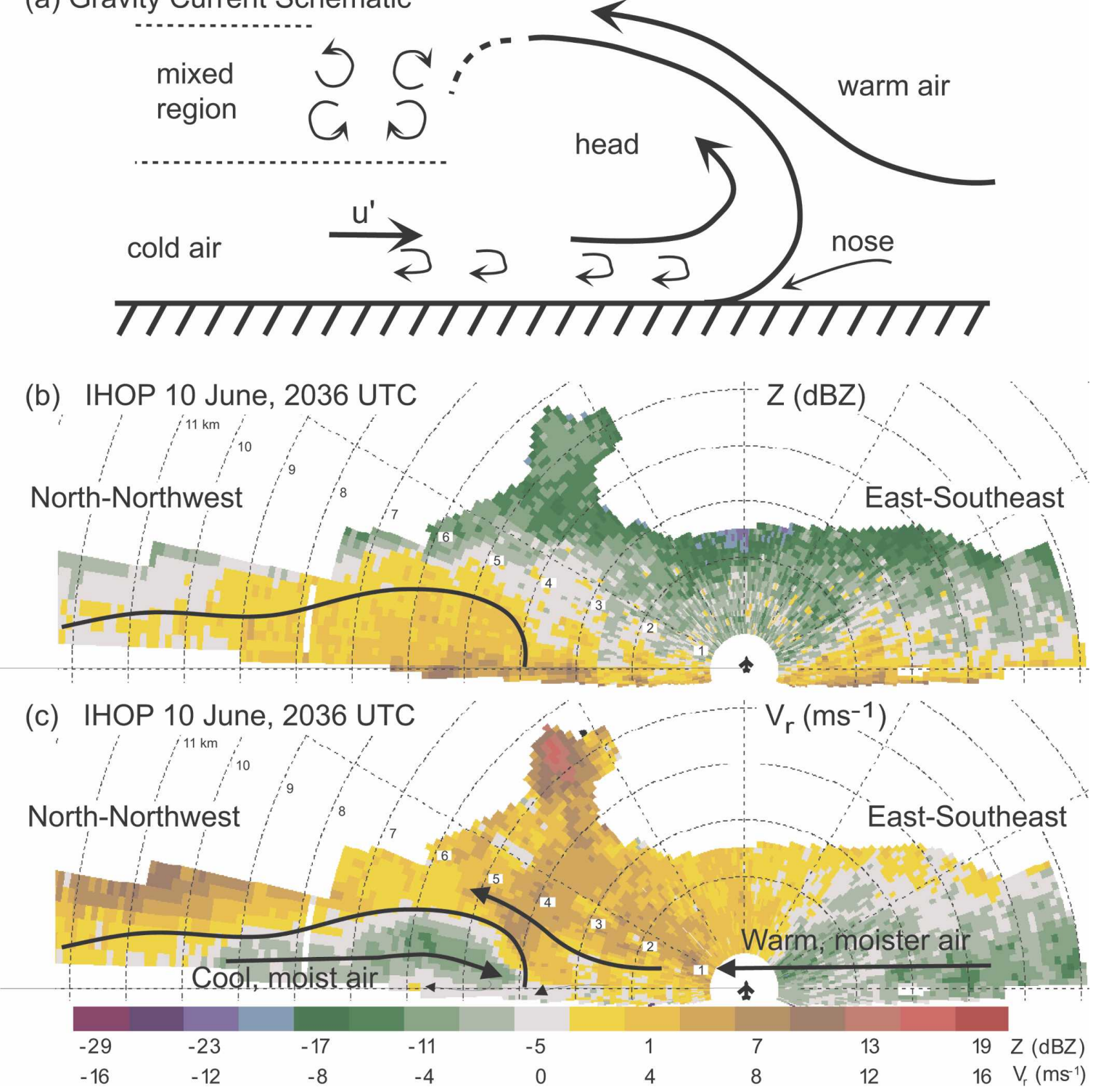

FIG. 15. (a) Conceptual model of the kinematic structures in an atmospheric gravity current (modified from Smith and Reeder 1988). Streamlines are indicated by lines with arrowheads; magnitude is related to their thickness. The solid line terminated by dashes indicates the interface between the warm and cold air. Vertical cross section of the color-coded ELDORA (b) reflectivity and (c) radial velocity (scales at the bottom) measured during the aft scan of the antenna at 2036 UTC (P3-Leg7). Positive (negative) radial velocity represents movement away from (toward) the aircraft. Range rings are centered around the aircraft (indicated by aircraft symbol) flying at 1.3-km MSL. The kinematic boundary based on Fig. 10 and the Doppler velocity in (c) is indicated as solid line. The conceptualized airflow is depicted by lines with arrowheads in (c); line thickness is related to the magnitude and primarily based on observations shown in Fig. 10.

moving cold fronts is still unclear. Several studies have shown that stationary or slow-moving sea-breeze fronts exhibit gravity current characteristics (e.g., Simpson 1969; Atkins and Wakimoto 1997; Kingsmill and Crook 2003).

An essential feature of a gravity current is that the magnitude of the feeder flow positioned behind and directed normal to the front (denoted as $u^{\prime}$ ) must be greater than the speed of the front (denoted as $c$ ) over a considerable depth and horizontal extent. The frontal propagation speeds derived from the spatial displacement of the MMR surface temperature gradient indicating the location of the cold front (Fig. 12) were $\sim 2.4$ $\mathrm{m} \mathrm{s}^{-1}$ between 1829 and 1911 UTC and $\sim 1.5 \mathrm{~m} \mathrm{~s}^{-1}$ between 1911 and 2018 UTC. According to the ELDORA radar reflectivity at $1.5 \mathrm{~km}$, the front moved 
TABLE 5. Parameters and measurement uncertainty necessary for the Froude number calculation in Eq. (1).

\begin{tabular}{lc}
\hline \hline Mean kinematic boundary depth based on mean vertical cross sections) & $\sim 600 \pm 250 \mathrm{~m}$ \\
Ambient airflow ahead of and orthogonal to the cold front (based on mean vertical cross sections) & $\sim 3 \pm 0.5 \mathrm{~m} \mathrm{~s}^{-1}$ \\
Mean $\theta_{v}$ ahead of the cold front (based on radiosondes with an uncertainty in mixing ratio of $\left.\sim 1 \mathrm{~g} \mathrm{~kg}^{-1}\right)$ & $316.6 \pm 0.5 \mathrm{~K}$ \\
Early afternoon (1900 UTC)/northern extent & $318.3 \pm 0.5 \mathrm{~K}$ \\
Late afternoon (2044 UTC)/southern extent & $316.0 \pm 0.5 \mathrm{~K}$ \\
Mean $\theta_{v}$ behind of the cold front (based on dropsondes) & $317.1 \pm 0.5 \mathrm{~K}$ \\
Early afternoon (1939 UTC)/northern extent & $3.3 \pm 1.4 \mathrm{~m} \mathrm{~s}^{-1}$ \\
Late afternoon (2054 UTC)/southern extent & $4.7 \pm 2.0 \mathrm{~m} \mathrm{~s}^{-1}$ \\
Densimetric speed & \\
Early afternoon (1900 UTC) & $2.4 \pm 1 \mathrm{~m} \mathrm{~s}^{-1}$ \\
Late afternoon (2044 UTC) & $1.5 \pm 1 \mathrm{~m} \mathrm{~s}{ }^{-1}$ \\
Speed of the cold front & $1.4 \pm 1 \mathrm{~m} \mathrm{~s}{ }^{-1}$ \\
Early afternoon (1900 UTC; based on MMR temperature) & $0.3 \pm 1 \mathrm{~m} \mathrm{~s}^{-1}$ \\
Late afternoon (2044 UTC; based on MMR temperature) & \\
Northern extent (1830-2030 UTC; based on ELDORA reflectivity) & \\
Southern extent (1830-2030 UTC; based on ELDORA reflectivity) &
\end{tabular}

southeastward with a speed of $1.4 \mathrm{~m} \mathrm{~s}^{-1}$ on its northeastern extent and $0.3 \mathrm{~m} \mathrm{~s}^{-1}$ on its southwestern extent between 1844 and 2041 UTC. The front-normal wind speed in the cool air sector was $\sim 2-4 \mathrm{~m} \mathrm{~s}^{-1}$ over the entire horizontal extent of the measurement $(\sim 20 \mathrm{~km})$ and up to $\sim 1.3 \mathrm{~km}$ MSL. Horizontal wind measurements derived from airborne Doppler radar are assumed to have an accuracy of $\pm 1 \mathrm{~m} \mathrm{~s}^{-1}$. The mean front-normal cross sections were derived from 70 to 207 individual cross sections for each flight leg. Through the averaging process to calculate these mean cross sections, the amount of correlation between the horizontal wind errors is unknown. If they are all correlated, then the mean cross-section error would be $\pm 1 \mathrm{~m} \mathrm{~s}^{-1}$ whereas if they are anticorrelated, the errors would effectively cancel and the mean cross-section error would be $0 \mathrm{~m} \mathrm{~s}^{-1}$. We assume a middle ground of $\pm 0.5 \mathrm{~m} \mathrm{~s}^{-1}$, which lies between these two extrema. Note also that Fig. 10 only reveals the feeder flow between 1 and 1.3 $\mathrm{km}$, which covers only the upper part of the post-cold frontal air mass according to Arnott et al. (2006). They measured an average front-relative flow between the ground and $1.3 \mathrm{~km} \mathrm{MSL} \mathrm{of} 5-10 \mathrm{~m} \mathrm{~s}^{-1}$ at 1946 UTC and $<5 \mathrm{~m} \mathrm{~s}^{-1}$ at 2036 UTC (Fig. 12 in Arnott et al. 2006). Although the difference between $u^{\prime}$ and $c$ was rather small in Fig. 10 and $c$ differed in space and time, the evidence suggests that $u^{\prime}>c$ in both the early and late afternoon, thus net low-level mass transport forward relative to the leading edge of the front occurred.

Since an atmospheric gravity current is primarily a horizontal flow driven by density differences, the leading edge should be characterized by a Froude number between 0.7 and 1.4 in calm conditions (Benjamin 1968). Simpson and Britter (1980) showed that Froude numbers decrease slightly in the presence of a head wind. The calculation of the Froude number is based on equations used by Benjamin (1968) and Simpson and Britter (1980)

$$
\operatorname{Fr}=\frac{\left(c-b u_{0}\right)}{u_{*}},
$$

where $u_{*}$ is the densimetric speed, $u_{0}$ is the frontnormal head wind speed (negative sign), and $b=0.6$. The densimetric speed is calculated according to

$$
u_{*}=\left(g \bar{h} \frac{\overline{\theta_{\mathrm{vw}}}-\overline{\theta_{\mathrm{vc}}}}{\overline{\theta_{\mathrm{vc}}}}\right)^{1 / 2},
$$

where $\overline{\theta_{\mathrm{vc}}}\left(\overline{\theta_{\mathrm{vw}}}\right)$ is the mean virtual potential temperature over the depth and behind (ahead of) the cold front, $\bar{h}$ is the mean kinematic boundary depth, and $g$ is the acceleration due to gravity. Froude numbers calculated from (1) using parameters listed in Table 5 were within the range characteristic for gravity currents decreasing from $1.3\left(c=2.4 \mathrm{~m} \mathrm{~s}^{-1}\right)$ in the early to 0.8 $\left(c=1.5 \mathrm{~m} \mathrm{~s}^{-1}\right)$ in the late afternoon when using propagation speeds based on the surface temperatures observed by the MMR. The uncertainties in these Froude numbers are \pm 0.6 in the early afternoon and \pm 0.4 in the late afternoon based on the Gaussian propagation of uncertainties for each variable in Eq. (1), which are listed in Table 5. A complementary analysis of Froude numbers and their uncertainty based on propagation speeds derived from ELDORA reflectivity between 1830 and 2030 UTC also reveals Froude numbers that are characteristic for gravity currents, with values of $1.0 \pm 0.6$ on the northeast end and $0.5 \pm 0.3$ on the southwest end. For this calculation the propagation speeds derived from ELDORA data in the northern (southern) extent of the cold front were combined with the temperatures obtained in the early (late) afternoon, which were derived from the first (second) dropsonde 
series placed along the northern (southern) extent of the front (Table 5).

Low-level mass transport toward the cold front leading edge and Froude number analysis do not provide stringent tests of the applicability of gravity current theory to the 10 June cold front due to the large uncertainty of measured quantities and their high temporal and spatial variation. Smith and Reeder (1988) concluded that the overall cold frontal structure also needs to resemble that of a gravity current (Fig. 15a). The analysis of several individual vertical cross sections (e.g., vertical cross section at 2036 UTC in Figs. 15b,c) and the mean kinematic cold frontal structures (Fig. 10) of the 10 June case showed flow structures similar to what is depicted in gravity current schematic. A feeder flow of $\sim 2-4 \mathrm{~m} \mathrm{~s}^{-1}$ toward the leading edge in the cool air sector was observed along the slowly propagating cold front $\left(0.3<c<2.4 \mathrm{~m} \mathrm{~s}^{-1}\right)$. Other typical features are the reverse flow close to the ground, which is related to friction, and the pronounced return or upstream flow (Fig. 15c) at the leading edge, which increased with time (Fig. 10). This flow produced an updraft $\left(\sim 0.5-1 \mathrm{~m} \mathrm{~s}^{-1}\right)$ that was located at the cold front leading edge both within the cool and warm air mass (Fig. 10). A pronounced rotor circulation within the cool air was observed in the cool air mass.

Laboratory experiments also show an elevated head in advance of the gravity current with a series of lobes and clefts that continually change their shape (Simpson 1969). An elevated hydraulic head followed by a wakelike flow was observed in nonprecipitating cold fronts by Young and Johnson (1984) and Shapiro et al. (1985). The temporal and spatial resolution of the measurements on 10 June is too coarse to resolve any lobe and cleft structures. However, vertically elevated bulges were observed at the cold front leading edge in the mixing ratio (Fig. 6) along individual cross section and in the radar reflectivity fields of all of the mean cross sections (Fig. 10). The horizontal extent of the feeder flow $(>20 \mathrm{~km})$ exceeded the horizontal extent of those bulges $(\sim 10 \mathrm{~km})$, another characteristic of a density current according to Smith and Reeder (1988).

A sharp change in density and pressure on the passage of the cold front was not revealed by the data collected on 10 June. Horizontal transects from the UW King Air in situ measurements showed only a slight jump in pressure of $\sim 2.5 \mathrm{hPa}$ and potential temperature of $\sim 0.5 \mathrm{~K}$ located at $1.2 \mathrm{~km}$ MSL over $\sim 2.5 \mathrm{~km}$ in an area with a sharp gradient of wind speed and direction (Fig. 8). The validity of these numbers remains somewhat uncertain since the flight altitude varied by 50-80 $\mathrm{m}$ along this track. Also, only the upper part of the boundary was intersected at this flight altitude.
Along the lowest flight leg $(0.9 \mathrm{~km} \mathrm{MSL})$, the aircraft altitude varied by $\sim 100 \mathrm{~m}$, which created an extreme bias in the pressure measurements. Note that these sharp changes occur on a $\sim 1-\mathrm{km}$ scale. Shapiro et al. (1985) observed a temperature gradient of 4-8 K over a $\sim 1-\mathrm{km}$ horizontal scale across a cold front showing characteristics of a hydraulic frontal head.

Our results suggest that the applicability of gravity current theory to this very slow-moving cold front on 10 June strongly depends on the uncertainties of the measured quantities. There is evidence for certain gravity current characteristics: the Froude number and the overall kinematic structure shown in the pronounced rotor circulation, the $\sim 2 \mathrm{~m} \mathrm{~s}^{-1}$ feeder flow toward the leading edge, an undercurrent flow close to the ground, an elevated head structure followed by a wakelike, rearward flow, and the upstream flow at the leading edge. However, other characteristics (e.g., a sharp change in density and pressure, lobe, and cleft structures) remain uncertain due to the temporally and spatially variable nature of the phenomenon and the coarse resolution and nonoptimized placement of measurements.

More comprehensive high-resolution measurements of temperature, moisture, and wind across slow-moving cold fronts are necessary to assess and extend the findings from this case study. A good example of an approach to employ was impressively demonstrated by Geerts et al. (2006). They revealed with great detail gravity current characteristics such as nose and head structures, feeder flow, and front-to-rear flow along a fast-moving cold front using data from the $94-\mathrm{GHz}$ Wyoming cloud radar. With spatial resolution of $40 \mathrm{~m}$ they were able to resolve not only gravity current characteristics but also breaking Kelvin-Helmholtz waves. A larger number and closer horizontal spacing of vertical temperature and moisture profiles across and behind the cold front will also be needed in future experiments to better monitor the temporal and spatial variation of Froude numbers.

\section{Summary and conclusions}

The kinematic and moisture structure of a slowmoving, nonprecipitating cold front observed in westcentral Kansas on 10 June 2002 during IHOP has been examined with a wide array of ground-based and airborne instrumentation that included in situ sensors, sounding systems, Doppler radars, a microwave radiometer, and a differential absorption lidar. Intensive observations were collected across a $\sim 40$-km-wide swath that straddled a $\sim 100-\mathrm{km}$ segment of the front. Less horizontally concentrated observations were collected over a wider across-front swath of about $200 \mathrm{~km}$. 
(a) Early afternoon

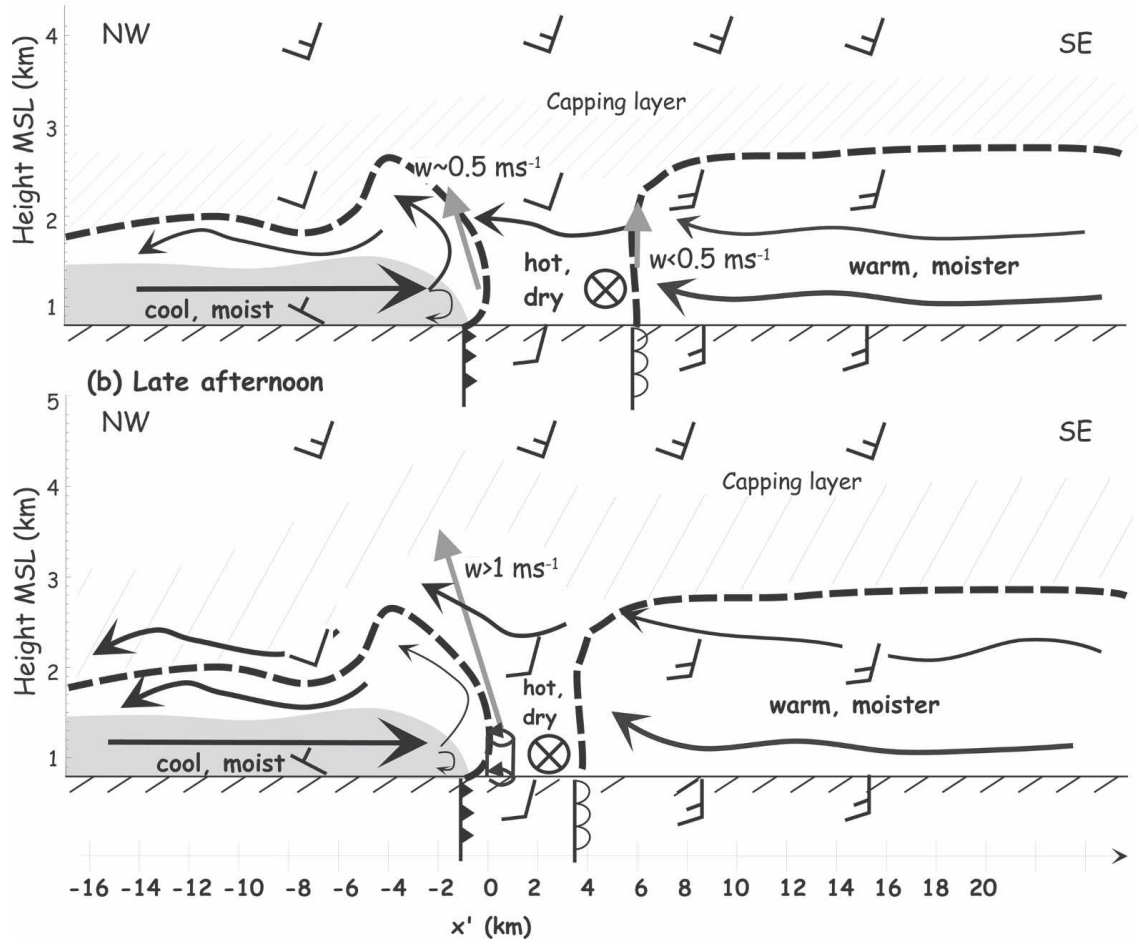

FIG. 16. Schematic diagram showing the kinematic and moisture structures across the cold front during the (a) early (1800-2000 UTC) and (b) late (2000-2200 UTC) afternoon on 10 Jun 2002. The interfaces separating the cool, less moist air located to the northwest and the warm, moister air located to the southeast from the hot, dry air near the surface and environmental air aloft are depicted as dashed black lines. The kinematic boundary defined as the zero across-front wind speed is highlighted in gray. Streamlines are indicated as black lines with arrowheads: thickness is related to the magnitude of the wind vectors. Vertical velocity is represented by upward-pointing gray arrows; length is related to magnitude. Location of maxima in vertical vorticity $\left(\zeta_{\max }\right)$ is highlighted as a rotating tube symbol in (b). More dense hatching for the capping layer corresponds to stronger stability.

The investigation focused on structures observed in the across-front dimension. A conceptual model of the conditions across the cold front is presented in Fig. 16. In the early afternoon between 1800 and 2000 UTC (Fig. 16a), the slow-moving, nonprecipitating cold front was located in the northwest half of the observation domain. The cool air sector was characterized by a pronounced northwesterly feeder flow of $\sim 2-4 \mathrm{~m} \mathrm{~s}^{-1}$ toward the cold front leading edge that reached up to $\sim 1.5 \mathrm{~km}$ MSL. A rotor circulation located at the leading edge merged into a rearward-directed return flow of $\sim 2 \mathrm{~m} \mathrm{~s}^{-1}$ above the feeder flow (indicated by streamlines in Fig. 16a). The weak rearward-directed undercurrent flow was only observed in individual cross sections (Fig. 15). The cold front leading edge was tilted back to the northwest about $8 \mathrm{~km}$ in the horizontal for every $1 \mathrm{~km}$ in the vertical and the average updraft at the frontal interface was about $0.5 \mathrm{~m} \mathrm{~s}^{-1}$ (gray arrow in Fig. 16a). Immediately ahead of the cold front was a $10-\mathrm{km}$ - wide band of hot, dry boundary layer air with $\sim 5 \mathrm{~m} \mathrm{~s}^{-1}$ winds out of the south-southwest. The largest horizontal gradients in wind and moisture were observed below $1.5 \mathrm{~km}$. A dryline was located to the southeast, separating the hot, dry air mass immediately ahead of the cold front from a warm air mass advected from the south that was moister $\left(q \sim 11-14 \mathrm{~g} \mathrm{~kg}^{-1}\right)$ than the air behind the cold front $\left(q \sim 8-11 \mathrm{~g} \mathrm{~kg}^{-1}\right)$. The change in wind direction along this dryline was less distinct than the cold front, with only a $20^{\circ}-30^{\circ}$ wind shift. Weak upward motions less than or equal to $0.5 \mathrm{~m} \mathrm{~s}^{-1}$ were observed (gray arrow in Fig. 16a). All three air masses were capped by a strong stable layer at about $2-2.5 \mathrm{~km}$ indicated by the hatched area.

Later in the afternoon between 2000 and 2200 UTC (Fig. 16b) the temperature gradient across the front weakened due to diabatic heating in the cloud-free cool air mass. At the same time, the warm, moister boundary layer air approached the cold front from the south. 
The evolution of the hot, dry air ahead of the cold front was not well documented by the dropsondes because the first series during the early afternoon was placed too far north. The dryline was still well observed in the southwestern part of the observational domain while it vanished almost completely in the northeastern part. At the cold front leading edge, wind shear, low-level convergence $\left(\sim 1 \times 10^{-3} \mathrm{~s}^{-1}\right)$, and vertical vorticity $\left(\sim 0.5 \times 10^{-3} \mathrm{~s}^{-1}\right.$; indicated as a rotating tube symbol in Fig. 16b) increased in the layer from the surface up to $\sim 1.5 \mathrm{~km}$ MSL. The mean updraft within the frontal convergence zone was deeper and more intense than earlier with peak magnitudes $\sim 1 \mathrm{~m} \mathrm{~s}^{-1}$ (gray arrows in Fig. $16 \mathrm{~b})$ and was still tilted back $\left(\sim 7^{\circ}\right)$ over the cool air. The wakelike flow on top of the cool air became more pronounced. Clouds formed after 2030 UTC behind the cold front leading edge and above the cool air. With a mean updraft of $\sim 1 \mathrm{~m} \mathrm{~s}^{-1}$, the time required to lift air parcels up to the $\sim 3.6 \mathrm{~km}$ MSL LFC was about 30-60 min. However, in local areas where updraft magnitudes exceeded $\sim 4 \mathrm{~m} \mathrm{~s}^{-1}$, this time would be as short as $15 \mathrm{~min}$. During the late afternoon, thermodynamic conditions became more favorable for convection initiation. The strong stable layer weakened (Figs. 5 and 6). The DDC radiosonde at 2100 UTC reported an increase in CAPE to $2479 \mathrm{~J} \mathrm{~kg}^{-1}$ and a decrease in CIN to $130 \mathrm{~J} \mathrm{~kg}^{-1}$ relative to the $1800 \mathrm{UTC}$ radiosonde (Table 1). Moisture increased in the layer between 2 and $4 \mathrm{~km}$ MSL.

Evidence for certain gravity current characteristics was found at the cold front leading edge: Froude numbers between 0.7 and 1.4, a pronounced front-normal feeder flow toward the cold front leading edge, a rotor circulation, vertically elevated bulges in mixing ratio and radar reflectivity, reverse flow close to the ground, and pronounced updrafts. Other characteristics such as a sharp change in pressure and lobe and cleft structures remain uncertain due to the temporally and spatially variable nature of the phenomenon and the coarse resolution of the measurements.

In addition to being important in their own right, the across-front structures described in this paper provide an important two-dimensional context that lays the foundation for a more complete three-dimensional description of the 10 June 2002 cold front case. In Part II of this study, the emphasis will shift to documenting kinematic and moisture structures observed in the alongfront dimension. More specifically, attention will be focused on the three-dimensional organization of vertical velocity, vertical vorticity, and horizontal vorticity along and behind the front and whether they may play a role in convection initiation.
Acknowledgments. We extend special thanks to Yvette Richardson of The Pennsylvania State University, Tammy Weckwerth of NCAR, and Paul Neiman, and John Brown of NOAA for many fruitful discussions regarding this paper. We thank the four anonymous reviewers for providing comments and suggestions that enhanced the quality of the paper. Editing and interpolation of radar data were performed using the SOLO and REORDER programs. Dual-Doppler analyses were performed using the CEDRIC program. Huanqing Cai, Micheal Bell, and Wen-Chau Lee of NCAR assisted in the installation and operation of the tuning fork software to correct ELDORA data for navigation errors. Huaqing Cai also processed the raw mobile microwave radiometer data to produce the derived integrated water vapor and liquid water parameters. Ming Xiao of DRI assisted with the editing of radar data. This research was sponsored by the National Science Foundation under Grants ATM-9901688, ATM-0432951 (Friedrich and Kingsmill), and ATM021048 (Murphey and Wakimoto).

\section{REFERENCES}

Arnott, N. R., Y. P. Richardson, J. M. Wurman, and E. M. Rasmussen, 2006: Relationship between a weakening cold front, misocyclones, and cloud development on 10 June 2002 during IHOP. Mon. Wea. Rev., 134, 311-335.

Atkins, N. T., and R. M. Wakimoto, 1997: Influence of the synoptic-scale flow on sea breezes observed during CaPE. Mon. Wea. Rev., 125, 2112-2130.

$\longrightarrow,-$, and T. M. Weckwerth, 1995: Observations of the seabreeze front during CaPE. Part II: Dual-Doppler and aircraft analysis. Mon. Wea. Rev., 123, 944-969.

Barnes, S. L., 1973: Mesoscale objective map analysis using weighted time-series observations. NOAA Tech. Memo. ERL NSSL-62, 60 pp.

Benjamin, T. B., 1968: Gravity currents and related phenomena. $J$. Fluid Mech., 31, 209-243.

Blanchard, D. O., and R. E. Lopez, 1985: Spatial patterns of convection in south Florida. Mon. Wea. Rev., 113, 1282-1299.

Bond, N. A., and M. A. Shapiro, 1991: Research aircraft observations of the mesoscale and microscale structure of a cold front over the eastern Pacific Ocean. Mon. Wea. Rev., 119, 3080 3094.

Bosart, B. B., W.-C. Lee, and R. M. Wakimoto, 2002: Procedures to improve the accuracy of airborne Doppler radar data. $J$. Atmos. Oceanic Technol., 19, 322-339.

Brandes, E. A., and R. M. Rabin, 1991: Probing a nonprecipitating cold front with Doppler weather radar. J. Atmos. Oceanic Technol., 8, 409-421.

Braun, S. A., R. A. Houze Jr., and B. F. Smull, 1997: Airborne dual-Doppler observations of an intense frontal system approaching the Pacific northwest coast. Mon. Wea. Rev., 125, 3131-3156.

Bruneau, D., P. Quaglia, C. Flamant, M. Meissonnier, and J. Pelon, 2001: Airborne lidar LEANDRE II for water-vapor profiling in the troposphere. I. System description. Appl. Opt., 40, 3450-3461. 
Byers, H. R., and R. R. Braham, 1949: The Thunderstorm. U.S. Government Printing Office, $287 \mathrm{pp}$.

Carbone, R. E., 1982: A severe frontal rainband. Part I: Stormwide hydrodynamic structure. J. Atmos. Sci., 39, 258-279.

—, M. J. Carpenter, and C. D. Burghart, 1985: Doppler radar sampling limitations in convective storms. J. Atmos. Oceanic Technol., 2, 357-361.

Charba, J., 1974: Application of gravity current model to analysis of squall-line gust front. Mon. Wea. Rev., 102, 140-154.

Clarke, R. H., 1961: Mesostructure of dry cold fronts over featureless terrain. J. Meteor., 18, 715-735.

Cohen, R. A., and C. W. Kreitzberg, 1997: Airstream boundaries in numerical weather simulations. Mon. Wea. Rev., 125, 168183.

- and D. M. Schultz, 2005: Contraction rate and its relationship to frontogenesis, the Lyapunov exponent, fluid trapping, and airstream boundaries. Mon. Wea. Rev., 133, 1353-1369.

Cressman, G. P., 1959: An operational objective analysis system. Mon. Wea. Rev., 87, 367-374.

Crook, N. A., and M. W. Moncrieff, 1988: The effects of largescale convergence on the generation and maintenance of deep moist convection. J. Atmos. Sci., 45, 3606-3624.

Fovell, R. G., 2005: Convective initiation ahead of the sea-breeze front. Mon. Wea. Rev., 133, 264-278.

Friedrich, K., D. E. Kingsmill, and C. R. Young, 2005: Misocyclone characteristics along Florida gust fronts during CaPE. Mon. Wea. Rev., 133, 3345-3367.

Fujita, T. T., 1970: The Lubbock tornadoes: A study of suction spots. Weatherwise, 23, 160-173.

Garratt, J. R., 1988: Summertime cold fronts in southeast Australia-Behavior and low-level structure of main frontal types. Mon. Wea. Rev., 116, 636-649.

_ gravity currents. I: Simulations and observations of cold fronts. Contrib. Atmos. Phys., 59, 282-300.

Geerts, B., R. Damiani, and S. Haimov, 2006: Finescale vertical structure of a cold front as revealed by an airborne Doppler radar. Mon. Wea. Rev., 134, 251-271.

Hane, C. E., H. B. Bluestein, T. M. Crawford, M. E. Baldwin, and R. M. Rabin, 1997: Severe thunderstorm development in relation to along-dryline variability: A case study. Mon. Wea. Rev., 125, 231-251.

Hildebrand, H. P., C. A. Walther, C. L. Frush, J. Testud, and F. Baudin, 1994: The ELDORE/ASTRAIA airborne Doppler weather radar: Goals, design, and first field tests. IEEE Proc., 82, 1873-1890.

—, and Coauthors, 1996: The ELDORA/ASTRAIA airborne Doppler weather radar: High-resolution observations from TOGA COARE. Bull. Amer. Meteor. Soc., 77, 213-232.

Hobbs, P. V., and P. O. Persson, 1982: The mesoscale and microscale structure and organization of clouds and precipitation in midlatitude cyclones. Part V: The substructure of narrow cold-frontal rainbands. J. Atmos. Sci., 39, 280-295.

, T. J. Matejka, P. H. Herzegh, J. D. Locatelli, and R. A. Houze Jr., 1980: The mesoscale and microscale structure and organization of clouds and precipitation in midlatitude cyclones. I: A case study of a cold front. J. Atmos. Sci., 37, 568-596.

_ model for cyclones generated in the lee of the Rocky Mountains. Bull. Amer. Meteor. Soc., 77, 1169-1178.

Hogg, D. C., F. O. Guiraud, J. B. Snider, M. T. Decker, and E. R. Westwater, 1983: A steerable dual-channel microwave radi- ometer for the measurement of water vapor and liquid in the troposphere. J. Climate Appl. Meteor., 22, 789-806.

Huggins, A. W., 1995: Mobile microwave radiometer observations: Spatial characteristics of supercooled cloud water and cloud seeding implications. J. Appl. Meteor., 34, 432-466.

Hutchinson, T. A., and H. B. Bluestein, 1998: Prefrontal windshift lines in the plains of the United States. Mon. Wea. Rev., 126, 141-166.

James, P. K., and K. A. Browning, 1979: Mesoscale structure of line convection at surface cold fronts. Quart. J. Roy. Meteor. Soc., 105, 371-382.

Jorgensen, D. P., T. Matejka, and J. D. DuGranrut, 1996: Multibeam techniques for deriving wind fields from airborne Doppler radars. J. Meteor. Atmos. Phys., 59, 83-104.

, Z. Pu, P. O. G. Persson, and W.-K. Tao, 2003: Variations associated with cores and gaps of a Pacific narrow cold frontal rainband. Mon. Wea. Rev., 131, 2705-2729.

Keyser, D., M. J. Reeder, and R. J. Reed, 1988: A generalization of Petterssen's frontogenesis function and its relation to forcing of vertical motion. Mon. Wea. Rev., 116, 762-780.

Kingsmill, D. E., and N. A. Crook, 2003: An observational study of atmospheric bore formation from colliding density currents. Mon. Wea. Rev., 131, 2985-3002.

Koch, S. E., and J. McCarthy, 1982: The evolution of an Oklahoma dryline. Part II: Boundary-layer forcing of mesoconvective systems. J. Atmos. Sci., 39, 237-257.

_ , and W. L. Clark, 1999: A nonclassical cold front observed during COPS-91: Frontal structure and the process of severe storm initiation. J. Atmos. Sci., 56, 2862-2890.

- A. Aksakal, and J. T. McQueen, 1997: The influence of mesoscale humidity and evapotranspiration fields on a model forecast of a cold-frontal squall line. Mon. Wea. Rev., 125, 384-409.

Martin, J. E., J. D. Locatelli, P. V. Hobbs, P.-Y. Wang, and J. A. Castle, 1995: Structure and evolution of winter cyclones in the central United States and their effects on the precipitation. Part I: A synoptic-scale rainband associated with a lee dryline and lee trough. Mon. Wea. Rev., 123, 241-264.

Murphey, H. V., R. M. Wakimoto, C. Flamant, and D. E. Kingsmill, 2006: Dryline on 19 June 2002 during IHOP. Part I: Airborne Doppler and LEANDRE II analysis of the thin line structure and convection initiation. Mon. Wea. Rev., 134, 406-430.

Neiman, P. J., and R. M. Wakimoto, 1999: The interaction of a Pacific cold front with shallow air masses east of the Rocky Mountains. Mon. Wea. Rev., 127, 2102-2127.

O'Brien, J. J., 1970: Alternative solutions to the classical vertical velocity problem. J. Appl. Meteor., 9, 197-203.

Roux, F., V. Marecal, and D. Hauser, 1993: The 12/13 January 1988 narrow cold-frontal rainband observed during MFDP/ FRONTS 87. Part I: Kinematics and thermodynamics. $J$. Atmos. Sci., 50, 951-974.

Schaefer, J. T., 1974: The life cycle of the dryline. J. Appl. Meteor., 13, 444-449.

1986: The dryline. Mesoscale Meteorology and Forecasting, P. S. Ray, Ed., Amer. Meteor. Soc., 549-572.

Schultz, D. M., 2004: Cold fronts with and without prefrontal wind shifts in the Central United States. Mon. Wea. Rev., 132, 2040-2053.

— , and R. J. Trapp, 2003: Nonclassical cold-frontal structure caused by dry subcloud air in Northern Utah during the Intermountain Precipitation Experiment (IPEX). Mon. Wea. Rev., 131, 2222-2246. 
Shapiro, M. A., 1984: Meteorological tower measurements of a surface cold front. Mon. Wea. Rev., 112, 840-848.

—, T. Hampel, D. Rotzoll, and F. Mosher, 1985: The frontal hydraulic head: A micro- $\alpha$ scale $(\sim 1 \mathrm{~km})$ triggering mechanism for mesoconvective weather systems. Mon. Wea. Rev., 113, 1166-1183.

Simpson, J. E., 1969: A comparison between laboratory and atmospheric density currents. Quart. J. Roy. Meteor. Soc., 95, $758-765$.

—, and R. E. Britter, 1980: A laboratory model of an atmospheric mesofront. Quart. J. Roy. Meteor. Soc., 106, 485-500.

Smith, R. K., and M. J. Reeder, 1988: On the movement and lowlevel structure of cold fronts. Mon. Wea. Rev., 116, 19271944.

- — - N. J. Tapper, and D. R. Christie, 1995: Central Australian cold fronts. Mon. Wea. Rev., 123, 16-38.

Wakimoto, R. M., 1982: The life cycle of thunderstorm gust fronts as viewed with Doppler radar and rawinsonde data. Mon. Wea. Rev., 110, 1060-1082.

— cold front during FASTEX. Mon. Wea. Rev., 128, 2447-2470.

Weckwerth, T. M., and R. M. Wakimoto, 1992: The initiation and organization of convective cells atop a cold-air outflow boundary. Mon. Wea. Rev., 120, 2169-2187.
, and Coauthors, 2004: An overview of the International $\mathrm{H}_{2} \mathrm{O}$ Project (IHOP_2002) and some preliminary highlights. Bull. Amer. Meteor. Soc., 85, 253-277.

Westwater, E. R., and O. N. Strand, 1972: Inversion techniques. Remote Sensing of the Troposphere, V. E. Derr, Ed., U.S. Goverment Printing Office, 16-1-16-3.

Wilson, J. W., and W. E. Schreiber, 1986: Initiation of convective storms at radar-observed boundary-layer convergence lines. Mon. Wea. Rev., 114, 2516-2536.

Young, G. S., and R. H. Johnson, 1984: Meso- and microscale features of a Colorado cold front. J. Appl. Meteor., 23, 13151325.

Ziegler, C. L., and C. E. Hane, 1993: An observational study of the dryline. Mon. Wea. Rev., 121, 1134-1151.

—, and E. N. Rasmussen, 1998: The initiation of moist convection at the dryline: Forecasting issues from a case study perspective. Wea. Forecasting, 13, 1106-1131.

, - M. S. Buban, Y. P. Richardson, L. J. Miller, and R. M. Rabin, 2007: The "triple point" on 24 May 2002 during IHOP. Part II: Ground-radar and in situ boundary layer analysis of cumulus development and convection initiation. Mon. Wea. Rev., 135, 2443-2472. 